\title{
Molecular Dynamics Study the Factors Effecting the Structure of $\mathrm{MgSiO}_{3}$ Bulk
}

\author{
Dung Nguyen Trong ${ }^{1} \&$ Huy Nguyen Quoc ${ }^{1}$ \\ ${ }^{1}$ Faculty of Physics, Hanoi National University of Education, 136 Xuan Thuy, Cau giay, Ha Noi, Viet Nam \\ Correspondence: Dung Nguyen Trong, Faculty of Physics, Hanoi National University of Education, 136 Xuan \\ Thuy, Cau giay, Ha Noi, Viet Nam. E-mail: dungntsphn@gmail.com
}

Received: February 26, 2019

Accepted: March 23, 2019

Online Published: March 30, 2019

doi: 10.5539/jmsr.v8n2p10

URL: https://doi.org/10.5539/jmsr.v8n2p10

\begin{abstract}
This paper studies the effect of atomic numbers (N), N=2000atoms, 3000atoms, 4000atoms, 5000atoms, 6000 atoms at temperature $(\mathrm{T}), \mathrm{T}=300 \mathrm{~K} ; \mathrm{N}=5000$ atoms at $\mathrm{T}=300 \mathrm{~K}, 500 \mathrm{~K}, 1000 \mathrm{~K}, 1500 \mathrm{~K}, 2000 \mathrm{~K}, 2500 \mathrm{~K}, 3000 \mathrm{~K}$, $3500 \mathrm{~K} ; \mathrm{N}=5000$ atoms at $\mathrm{T}=300 \mathrm{~K}, 2000 \mathrm{~K}$ with pressure (P), $\mathrm{P}=0 \mathrm{GPa}, 20 \mathrm{GPa}, 40 \mathrm{GPa}, 60 \mathrm{GPa}, 80 \mathrm{GPa}, 100 \mathrm{GPa}$ on the structure of $\mathrm{MgSiO}_{3}$ bulk by Molecular Dynamics method (MD) with Born-Mayer potential (BM), periodic boundary conditions. The results were analyzed through the radial distribution function (RDF), coordination number, angle distribution, size (l), energy (E). The results showed that there are the effects of factors on the structure of $\mathrm{MgSiO}_{3}$ bulk. In addition, with the atomic number $(\mathrm{N})$, temperature $(\mathrm{T})$, different pressures $(\mathrm{P})$ at temperature $\mathrm{T}=300 \mathrm{~K}, 2000 \mathrm{~K}$ there are the appearance and disappearance of links $\mathrm{Si}-\mathrm{Si}, \mathrm{Si}-\mathrm{O}, \mathrm{O}-\mathrm{O}, \mathrm{Si}-\mathrm{Mg}, \mathrm{O}-\mathrm{Mg}$, $\mathrm{Mg}-\mathrm{Mg}$ and number of structural units $\mathrm{SiO}_{4}, \mathrm{SiO}_{5}, \mathrm{SiO}_{6}, \mathrm{MgO}_{3}, \mathrm{MgO}_{4}, \mathrm{MgO}_{5}, \mathrm{MgO}_{6}, \mathrm{MgO}_{7}, \mathrm{MgO}_{8}, \mathrm{MgO}_{9}$, $\mathrm{MgO}_{10}, \mathrm{MgO}_{11}, \mathrm{MgO}_{12}$
\end{abstract}

Keywords: Effect, Atomic Number, Temperature, Pressure, Structure, $\mathrm{MgSiO}_{3}$ Bulk, Molecular Dynamics

\section{Introduction}

$\mathrm{MgSiO}_{3}$ is a compound of two materials $\mathrm{MgO}, \mathrm{SiO}_{2}$. In it, $\mathrm{MgO}$ is a widely used oxide in science and technology as bioactive (Pedone, Menziani, Segre, \& Cormack, 2008; Jallot, 2003; Pedone \& Menziani, 2009) and $\mathrm{SiO}_{2}$ is a silicate material with elasticity, density, high viscosity (Kraxner et al., 2008; Schilling et al., 2001; Lin, Chen, Liu, $\& \mathrm{Li}, 2007$ ) and is a main component of the earth's crust \& planets (Helfrich \& Wood, 2001; Molster et al., 1999; Dorschner et al.,1995). The synthesis of two $\mathrm{MgO}, \mathrm{SiO}_{2}$ material (Kohara et al., 2004) has been extensively studied in recent years (Kalampounias, Nasikas, \& Papatheodorou, 2009; Guignard \& Cormier, 2008; Sen, Maekawa, \& Papatheodorou, 2009; Taniguchi, Okuno, \& Matsumoto, 1997). Study the geology of the earth by using the structure of $\mathrm{MgO}, \mathrm{SiO}_{2}$ at high pressure (Sato \& Funamori, 2010) and when the pressure is high, the viscosity and diffusion coefficient in $\mathrm{MgSiO}_{3}$ change (Brawer, 1985; Liebau, 1984). There are many methods to study material: Experimental, theoretical and simulation. Experimental methods include: Absorption spectra (Sen, Maekawa, \& Papatheodorou, 2009), X-ray diffraction, neutron diffraction performed by Wilding et al. (Wilding, Benmore, Tangeman, \& Sampath, 2004) and Raman spectroscopy (Kalampounias, Nasikas, \& Papatheodorou, 2009). The theoretical methods include Monte Carlo (MC) method (Guignard \& Cormier, 2008) and molecular dynamics (MD) method. Experimental methods show that $\mathrm{MgSiO}_{3}$ is an important component in the process of forming the earth (Williams \& Garnero, 1996; Lay, Williams, \& Garnero, 1998) and this process occurs at high temperature, high pressure (Fiquet et al., 2010; Nomura et al., 2014; Nomura et al., 2011; Petitgirard et al., 2015). When studying the $\mathrm{MgSiO}_{3}$ material at high temperatures, high pressure is a condition causing equipment and funding difficulties to implement (Labrosse, Hernlund, \& Coltice, 2007) such as: it is not impossible to the study structure at $100 \mathrm{GPa}$ pressure at the present time, to solve this problem, it is necessary to use theoretical models (Karki, Bhattarai, \& Stixrude, 2007; Stixrude \& Karki, 2005). Along with that method, melting is performed at pressures below 10GPa (Sanloup et al., 2013). To overcome these difficulties, some studies have used alternative $\mathrm{SiO}_{2}$ to study the structure at high pressure (Sanloup, 2016). The results show that the coordination number increase from 4 to 6 at pressure (P), $\mathrm{P}=5 \div 40 \mathrm{GPa}$ (Meade, Hemley, \& Mao, 1992; Sato \& Funamori, 2008; Sato \& Funamori, 2010; Benmore et al., 2010) and coordination number is 6 when $\mathrm{P}=101.5 \mathrm{GPa}$. Brillouin scattering (Murakami \& Bass, 2010) showed the effect of $\mathrm{P}=140 \mathrm{GPa}$ on the deformation of the material. Recently, the results show that coordination number can be greater than 6 and the pressure can be up to 172GPa (Prescher et al., 2017; 
Kono et al., 2016). However, the results of $\mathrm{SiO}_{2}$ (Murakami \& Bass, 2011) do not provide direct information on the structure of $\mathrm{MgSiO}_{3}$. In addition, the results show that $\mathrm{Mg}$ in $\mathrm{MgSiO}_{3}$ has coordination number of 6 and octahedral structure (Wilding et al., 2004) (With four neighboring atoms $\mathrm{O}$ with a Mg-O link of $2.08 \AA$ and two neighboring atoms $\mathrm{O}$ with a $\mathrm{Mg}-\mathrm{O}$ link of $2.50 \AA$ ), or coordination number of 4 with a tetrahedral structure with an $\mathrm{Mg}$-O link of

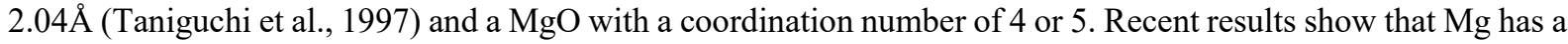
coordination number of 6 (Shimoda \& Okuno, 2006) and $\mathrm{MgSiO}_{3}$ has phase transition temperature $\left(\mathrm{T}_{\mathrm{m}}\right)$, $\mathrm{T}_{\mathrm{m}}=2150 \mathrm{~K}$. When the temperature increases $(\mathrm{T})$ near the crystallization temperature $\left(\mathrm{T}_{\mathrm{g}}\right)$, the viscosity increases (Kohara et al., 2004). The linking length of $\mathrm{MgSiO}_{3}$ with simulation method is $2.28 \AA$, neutron diffraction method and X-ray diffraction method combined with Monte Carlo method (MC) is $2.23 \AA$ (Sato \& Funamori, 2010). With the simulation method, the coordination number of $\mathrm{Mg}$ is 5 or 6 and the coordination number of 6 is dominant (Spera et al., 2011; Kohara et al., 2011). With the combination of X-ray diffraction method, neutron diffraction method with Monte Carlo simulation method, the coordination number of $\mathrm{Mg}$ in $\mathrm{MgSiO}_{3}$ is 4 or 5 Taniguchi et al., 1997; Spera et al., 2011; Kohara et al., 2011; Shimoda \& Okuno, 2006; Klotz et al., 1995; Cormier \& Cuello, 2011; Lee et al., 2005; Kubicki \& Lasaga, 1991; Benmore et al., 2011; Al-Hasni \& Mountjoy, 2014). However, with other results, the coordination number is greater than 5.1 (Lee et al., 2005) and $\mathrm{MgSiO}_{3}$ structure is synthesized $\mathrm{MgO}_{4}, \mathrm{MgO}_{5}$ with $\mathrm{SiO}_{4}$. This shows that experimental methods and simulation methods are the main tool to study $\mathrm{MgSiO}_{3}$ structure at amorphous state, liquid state, and especially to study the structure at room temperature and phase transition temperature at high pressure with a linking length of $\mathrm{Mg}-\mathrm{O}$ of $1.9 \div 1.96 \AA$ (Matsui \& Kawamura, 1980). Meanwhile, Kubicki and Lasagna have studied Mg in a deformed model with 3 or 4 neighboring atoms $\mathrm{O}$, the bonding length of Mg-O is $2 \AA$ and O-O is $2.2 \AA$ (Kubicki \& Lasagna, 1991; Kubicki \& Lasaga, 1991). With the recent results, the linking length of $\mathrm{Mg}-\mathrm{O}$ is $2.07 \AA$ and the coordination number is 5 or 7 . However, factors effecting the structure as atomic number, temperature and pressure at different temperatures have not been elucidated and what will happen to the structure if the pressure is high at room temperature $300 \mathrm{~K}$, high temperature $2000 \mathrm{~K}$, this is very interesting and necessary for applications in the glass industry and Earth.

\section{Calculation Method}

Initially, $\mathrm{MgSiO}_{3}$ bulks with atomic number (N), N=2000 atoms, 3000 atoms, 4000 atoms, 5000 atoms, 6000 atoms were randomly placed into the cube by Molecular Dynamics (MD) method with the Born-Mayer (BM) potential and recirculating boundary conditions (Dung, 2018).

$$
U_{i j}(r)=\frac{Z_{i} Z_{j} e^{2}}{r}+A_{i j} \exp \left(-B_{i j} r_{i j}\right)-\frac{C_{i j}}{r_{i j}^{6}}
$$

In which: $\mathrm{U}_{\mathrm{ij}}(\mathrm{r})(\mathrm{eV})$ is the pairing potential energy; $\mathrm{r}_{\mathrm{ij}}(\AA)$ is the distance between atoms; The coefficients $\mathrm{A}_{\mathrm{ij}}, \mathrm{B}_{\mathrm{ij}}$, $\mathrm{C}_{\mathrm{ij}}$ are determined from elastic and network constants; $Z_{i}, Z_{j}$ are the charges of ions $\mathrm{i}$ and $\mathrm{j}$, respectively, shown in Table 1.

Table 1. The parameters of $\mathrm{MgSiO}_{3}$ bulk

\begin{tabular}{lllllll}
\hline & $\mathrm{Si}-\mathrm{Si}$ & $\mathrm{Si}-\mathrm{O}$ & $\mathrm{O}-\mathrm{O}$ & $\mathrm{Si}-\mathrm{Mg}$ & $\mathrm{O}-\mathrm{Mg}$ & $\mathrm{Mg}-\mathrm{Mg}$ \\
\hline $\mathrm{A}_{\mathrm{ij}}(\mathrm{eV})$ & 0 & 1137.9639 & 2024.686563 & 0 & 1042.37635 & 0 \\
$\mathrm{~B}_{\mathrm{ij}}\left(\AA^{-1}\right)$ & 0 & 3.4373187 & 3.739716 & 0 & 3.25918353 & 0 \\
$\mathrm{C}_{\mathrm{ij}}\left(\AA^{-1}\right)$ & 0 & 0 & 3.3052647 & 0 & 0 & 0 \\
$\mathrm{Z}_{\mathrm{i}}(\mathrm{e})$ & 0 & 2.4 & -1.2 & 0 & 1.2 & 0 \\
\hline
\end{tabular}

Initially, all samples at temperature $(\mathrm{T}), \mathrm{T}=7000 \mathrm{~K}$ were lowered temperature to $\mathrm{T}=300 \mathrm{~K}$ with a heating rate of $10^{6} \mathrm{~K} / \mathrm{s}$ and time of each simulation step $\mathrm{MD}$ was $0.478 \mathrm{fs} ; \mathrm{MgSiO}_{3}$ bulks with 5000 atoms were increased in temperature from $\mathrm{T}=300 \mathrm{~K}$ to $\mathrm{T}=500 \mathrm{~K}, 1000 \mathrm{~K}, 1500 \mathrm{~K}, 2000 \mathrm{~K}, 2500 \mathrm{~K}, 3000 \mathrm{~K}, 3500 \mathrm{~K}$ at pressure $(\mathrm{P}), \mathrm{P}=0 \mathrm{GPa}$; $\mathrm{MgSiO}_{3}$ bulk model with 5000 atoms at temperature $\mathrm{T}=300 \mathrm{~K}, 2000 \mathrm{~K}$ increases at pressure from $\mathrm{P}=0 \mathrm{GPa}$ to $\mathrm{P}=20 \mathrm{GPa}, 40 \mathrm{GPa}, 60 \mathrm{GPa}, 80 \mathrm{GPa}, 100 \mathrm{GPa}$. With $\mathrm{MgSiO}_{3}$ bulk obtained, run $10^{5}$ step recovery statistics, run $2 \times 10^{5}$ step NVT (with constant atomic number, volume, the temperature), run $2 \times 10^{5}$ step NVP (with constant atomic number, volume, pressure) and run $4 \times 10^{5}$ step NVE (with constant atomic number, volume, energy) to the system reaches equilibrium. With samples at equilibrium, study the structure through radial distribution function (RDF), coordination number, energy $(\mathrm{E})$, size $(\mathrm{l})$, angle distribution and phase transition temperature $\left(\mathrm{T}_{\mathrm{m}}\right)$ through energy (E), temperature (T) and temperature of the system complying with the formula Nosé-Hoover (Nos'e, 1984; Hoover, 1985). 


\section{Results and Discussion}

\subsection{Effect of Atomic Number}

$\mathrm{MgSiO}_{3}$ bulk with atomic number $(\mathrm{N}), \mathrm{N}=2000$ atoms at a temperature ( $\left.\mathrm{T}\right), \mathrm{T}=300 \mathrm{~K}$ have structural shape, size (1), energy $(\mathrm{E})$ and radial distribution function (RDF), the results are shown in Figure 1, Figure 2 and Figure 3.

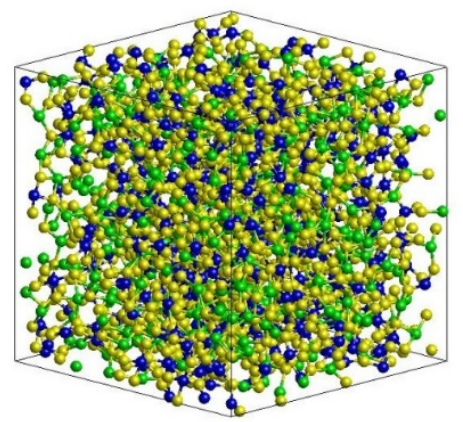

Figure 1. Structure shape of $\mathrm{MgSiO}_{3}$ bulk with 2000 atoms at $300 \mathrm{~K}$ temperature.
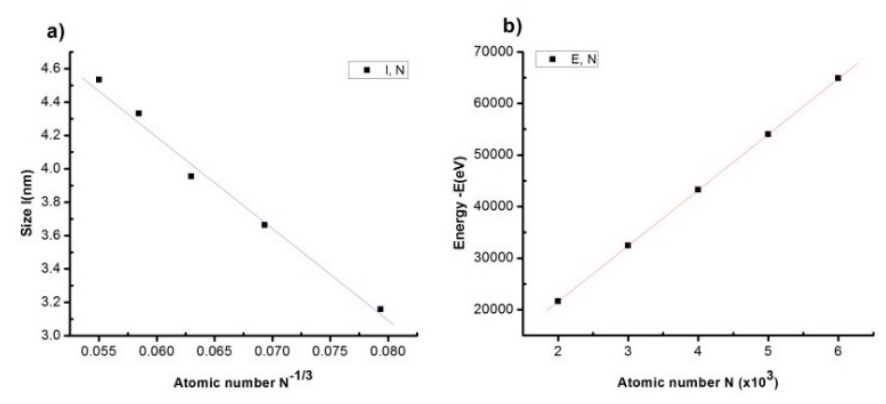

Figure 2. The energy, size of $\mathrm{MgSiO}_{3}$ bulk at temperature $300 \mathrm{~K}$ with different atomic numbers

The results show that $\mathrm{MgSiO}_{3}$ bulk with atomic number $(\mathrm{N}), \mathrm{N}=2000$ atoms at temperature $(\mathrm{T}), \mathrm{T}=300 \mathrm{~K}$ has cube-shaped and made of three atomic types (Figure 1) (blue of $\mathrm{Mg}$ dark, green of $\mathrm{Si}$, and yellow $\mathrm{O}$ ), size (1), $\mathrm{l}=3.157 \mathrm{~nm}$, energy $(\mathrm{E}), \mathrm{E}=-21623.33 \mathrm{eV}$. When increasing atomic number $(\mathrm{N})$, from $\mathrm{N}=2000$ atoms to $\mathrm{N}=3000$ atoms, 4000 atoms, 5000 atoms, 6000 atoms lead to an increase in size (Figure 2), satisfying the formula: $1=7.6$ $56 \mathrm{~N}^{-1 / 3}$, energy of sample decreases and proportional to $\mathrm{N}^{-}$. The results show that 1 proportional to $\mathrm{N}^{-1 / 3}$ and $\mathrm{E}$ proportional to $\mathrm{N}^{-}$. This result is perfectly consistent with previously published results such as crystallization temperature $\left(\mathrm{T}_{\mathrm{g}}\right)$ in proportion to $\mathrm{N}^{-1 / 3}$ (Qi et al., 2001) and size (l or $\left.\mathrm{D}\right)$ is proportional to $\mathrm{N}^{-1 / 3}$ with $\mathrm{Ni}$ nanoparticles or CuNi nanoparticles (Dung, 2018; Nguyen, 2017; Nguyen et al., 2017). To find out this, research the radial distribution function (RDF), the results are shown in Figure 3, Table $2 \mathrm{a}$ and Table $2 \mathrm{~b}$.

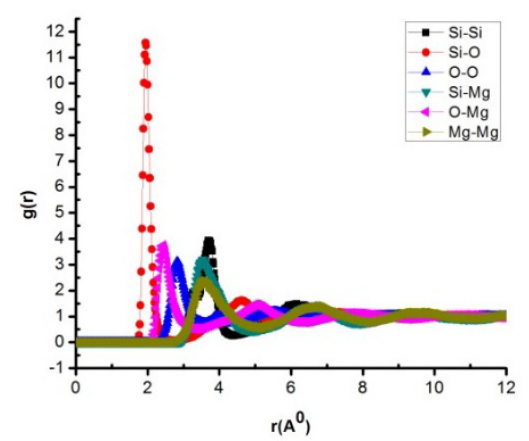

Figure 3. The radial distribution function of links $\mathrm{Si}-\mathrm{Si}, \mathrm{Si}-\mathrm{O}, \mathrm{O}-\mathrm{O}, \mathrm{Si}-\mathrm{Mg}, \mathrm{O}-\mathrm{Mg}, \mathrm{Mg}-\mathrm{Mg}$ at temperature $300 \mathrm{~K}$ 
Table 2a. The linking length of Si-Si, Si-O, O-O, Si-Mg, O-Mg, Mg-Mg with different atomic numbers

\begin{tabular}{lllllll}
\hline \multirow{2}{*}{ Atoms number (atoms) } & $\mathrm{r}_{\mathrm{ij}}(\AA)$ & & & & & $\mathrm{O}-\mathrm{Mg}$ \\
\hline 2000 & $\mathrm{Si}-\mathrm{Si}$ & $\mathrm{Si}-\mathrm{O}$ & $\mathrm{O}-\mathrm{O}$ & $\mathrm{Si}-\mathrm{Mg}$ & 2.49 & 3.58 \\
3000 & 3.7 & 1.94 & 2.82 & 3.54 & 2.44 & 3.6 \\
4000 & 3.72 & 1.94 & 2.82 & 3.54 & 2.42 & 3.58 \\
5000 & 3.68 & 1.96 & 2.82 & 3.52 & 2.42 & 3.6 \\
6000 & 3.68 & 1.94 & 2.84 & 3.56 & 2.42 & 3.56 \\
\hline
\end{tabular}

Table 2b. Height of radial distribution function of links Si-Si, Si-O, O-O, Si-Mg, O-Mg, Mg-Mg with different atomic numbers

\begin{tabular}{|c|c|c|c|c|c|c|}
\hline \multirow{2}{*}{ Atoms number (atoms) } & \multicolumn{6}{|l|}{$\mathrm{g}_{\mathrm{ij}}(\mathrm{r})$} \\
\hline & $\mathrm{Si}-\mathrm{Si}$ & $\mathrm{Si}-\mathrm{O}$ & $\mathrm{O}-\mathrm{O}$ & $\mathrm{Si}-\mathrm{Mg}$ & $\mathrm{O}-\mathrm{Mg}$ & $\mathrm{Mg}-\mathrm{Mg}$ \\
\hline 2000 & 3.93 & 11.57 & 3.12 & 3.2 & 3.75 & 2.37 \\
\hline 3000 & 3.93 & 12.29 & 3.09 & 3.07 & 3.94 & 2.25 \\
\hline 4000 & 3.78 & 11.69 & 3.16 & 3.23 & 3.71 & 2.46 \\
\hline 5000 & 3.87 & 11.88 & 3.03 & 3.07 & 3.85 & 2.3 \\
\hline 6000 & 3.87 & 11.23 & 3.09 & 3.1 & 3.73 & 2.39 \\
\hline
\end{tabular}

The results show that $\mathrm{MgSiO}_{3}$ bulk with $\mathrm{N}=2000$ atoms at $\mathrm{T}=300 \mathrm{~K}$ has the first peak position of links Si-Si, $\mathrm{Si}-\mathrm{O}$, $\mathrm{O}-\mathrm{O}, \mathrm{Si}-\mathrm{Mg}, \mathrm{O}-\mathrm{Mg}, \mathrm{Mg}-\mathrm{Mg}$ has to occupy a dominant position corresponding to linking length of is $3.7 \AA, 1.94 \AA$, $2.82 \AA, 3.54 \AA, 2.44 \AA, 3.58 \AA$ (Figure 3, Table 2a) and the height of the radial distribution function $\mathrm{g}(\mathrm{r})$ has a corresponding value of $3.93,11.57,3.12,3.2,3.75,2.37$. When increasing $\mathrm{N}$, from $\mathrm{N}=2000$ atoms to $\mathrm{N}=3000$ atoms, 4000 atoms, 5000 atoms, 6000 atoms, the first peak position of RDF and $\mathrm{g}(\mathrm{r})$ of the links are not significantly changed (Table $2 \mathrm{a}$ and Table $2 \mathrm{~b}$ ). This shows that the linking length of $\mathrm{Si}-\mathrm{Si}, \mathrm{Si}-\mathrm{O}, \mathrm{O}-\mathrm{O}, \mathrm{Si}-\mathrm{Mg}$, $\mathrm{O}-\mathrm{Mg}, \mathrm{Mg}-\mathrm{Mg}$ does not depend on the atomic number, there is no far distant order, but close order exists. To confirm the accuracy of the results, study the coordination numbers of the links in Table 3a, Table $3 \mathrm{~b}$.

Table 3a. The coordination number of links Si-Si, Si-O, O-O, Si-Mg, O-Mg, Mg-Mg at temperature 300K, pressure 0GPa with different atomic numbers

\begin{tabular}{ccccccc}
\hline Atoms number (atom) & Si-Si & Si-O & O-O & Si-Mg & O-Mg & Mg-Mg \\
\hline 2000 & 5 & 5 & 12 & 6 & 2 & 6 \\
3000 & 5 & 5 & 13 & 6 & 2 & 7 \\
4000 & 5 & 6 & 13 & 7 & 2 & 7 \\
5000 & 5 & 5 & 13 & 6 & 2 & 6 \\
6000 & 5 & 6 & 13 & 6 & 2 & 7 \\
\hline
\end{tabular}

Table $3 b$. The density of coordination number of links Si-Si, Si-O, O-O, Si-Mg, O-Mg, Mg-Mg at temperature $300 \mathrm{~K}$, pressure $0 \mathrm{GPa}$ with different atomic numbers

\begin{tabular}{lllllll}
\hline Atoms number (atom) & $\mathrm{Si}-\mathrm{Si}$ & $\mathrm{Si}-\mathrm{O}$ & $\mathrm{O}-\mathrm{O}$ & $\mathrm{Si}-\mathrm{Mg}$ & $\mathrm{O}-\mathrm{Mg}$ & $\mathrm{Mg}-\mathrm{Mg}$ \\
\hline 2000 & 100 & 206 & 290 & 85 & 390 & 74 \\
3000 & 176 & 338 & 421 & 141 & 618 & 119 \\
4000 & 206 & 407 & 587 & 178 & 855 & 160 \\
5000 & 263 & 545 & 702 & 229 & 1028 & 203 \\
6000 & 324 & 639 & 854 & 240 & 1205 & 234 \\
\hline
\end{tabular}

The results show that, with $\mathrm{N}=2000$ atoms then the coordination number of links $\mathrm{Si}-\mathrm{Si}$, Si-O, O-O, Si-Mg, O-Mg, $\mathrm{Mg}-\mathrm{Mg}$ has the corresponding value of 5, 5, 12, 6, 2,6. When increasing $\mathrm{N}$, from $\mathrm{N}=2000$ atoms to $\mathrm{N}=3000$ atoms, 4000 atoms, 5000 atoms, 6000 atoms, the coordination number of links Si-Si and O-Mg has constant value; the coordination numbers of links Si-O, O-O, Si-Mg, Mg-Mg are variable but not significant (Table 3a) and the density of coordination numbers of links $\mathrm{Si}-\mathrm{Si}$, Si-O, O-O, Si-Mg, O-Mg, Mg-Mg increases (Table 3b). 
The cause of the change in coordination number, the density of coordination numbers is due to heterogeneity in the sample: the increase in the number of atoms leads to the size (1), the energy (E) of the samples increases, the bonding length of $\mathrm{Si}-\mathrm{Si}, \mathrm{Si}-\mathrm{O}, \mathrm{O}-\mathrm{O}, \mathrm{Si}-\mathrm{Mg}, \mathrm{O}-\mathrm{Mg}$ increases leads to structural change. Next, using the visual method to study the number of structural units and the density of structural units of TOx links ( $\mathrm{T}$ is $\mathrm{Si}$ or $\mathrm{Mg}$ ), $\mathrm{x}=4$, 5, 6, 7, 8, 9, 10, 11, 12, results in Figure 4, Table 4a and Table 4b.
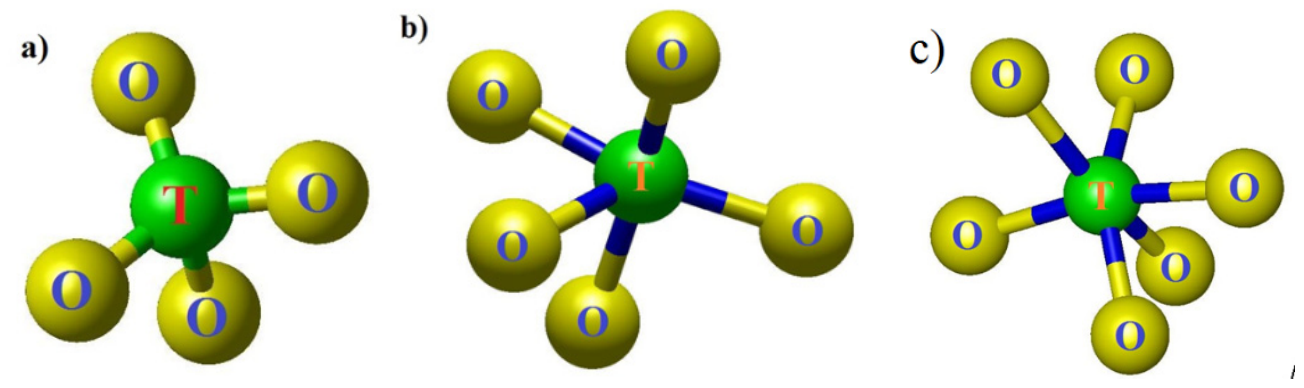

Figure 4. The number of structural units of $\mathrm{TO}_{\mathrm{x}}(\mathrm{T}$ is $\mathrm{Si}$ or $\mathrm{Mg}$ ) with $\mathrm{x}=4$ (Figure a), $\mathrm{x}=5$ (Figure $\mathrm{b}$ ), $\mathrm{x}=6$ (Figure

$$
\text { c), ... (Dung, 2018) }
$$

Table 4a. The number of structural units of $\mathrm{SiO}_{\mathrm{x}}, \mathrm{MgO}_{\mathrm{x}}$ of $\mathrm{MgSiO}_{3}$ bulk at temperature $300 \mathrm{~K}$, pressure $0 \mathrm{GPa}$ with different atomic numbers

\begin{tabular}{llllll}
\hline Atoms number (atom) & 2000 & 3000 & 4000 & 5000 & 6000 \\
\hline $\mathrm{SiO}_{4}$ (degrees) & 100 & 105 & 105 & 105 & 105 \\
$\mathrm{SiO}_{5}$ (degrees) & 90 & 90 & 90 & 90 & 90 \\
$\mathrm{SiO}_{6}$ (degrees) & 85 & 90 & 85 & 90 & 85 \\
$\mathrm{MgO}_{3}$ (degrees) & 0 & 0 & 0 & 0 & 0 \\
$\mathrm{MgO}_{4}$ (degrees) & 90 & 95 & 95 & 95 & 95 \\
$\mathrm{MgO}_{5}$ (degrees) & 90 & 90 & 90 & 90 & 80 \\
$\mathrm{MgO}_{6}$ (degrees) & 85 & 60 & 60 & 60 & 60 \\
$\mathrm{MgO}_{7}$ (degrees) & 60 & 60 & 60 & 60 & 60 \\
$\mathrm{MgO}_{8}$ (degrees) & 60 & 60 & 60 & 60 & 60 \\
$\mathrm{MgO}_{9}$ (degrees) & 60 & 60 & 60 & 55 & 60 \\
$\mathrm{MgO}_{10}$ (degrees) & 60 & 60 & 55 & 55 & 60 \\
\hline
\end{tabular}

Table $4 \mathrm{~b}$. The density of structural units of $\mathrm{SiO}_{\mathrm{x}}, \mathrm{MgO}_{\mathrm{x}}$ of $\mathrm{MgSiO}_{3}$ bulk at temperature $300 \mathrm{~K}$, pressure $0 \mathrm{GPa}$ with different atomic numbers

\begin{tabular}{|c|c|c|c|c|c|}
\hline Atoms number (atom) & 2000 & 3000 & 4000 & 5000 & 6000 \\
\hline $\mathrm{SiO}_{4}$ & 14 & 35 & 10 & 46 & 25 \\
\hline $\mathrm{SiO}_{5}$ & 325 & 511 & 613 & 840 & 829 \\
\hline $\mathrm{SiO}_{6}$ & 470 & 574 & 1050 & 1016 & 1593 \\
\hline $\mathrm{MgO}_{3}$ & 0 & 0 & 0 & 0 & 0 \\
\hline $\mathrm{MgO}_{4}$ & 7 & 23 & 9 & 33 & 47 \\
\hline $\mathrm{MgO}_{5}$ & 58 & 123 & 116 & 202 & 274 \\
\hline $\mathrm{MgO}_{6}$ & 141 & 251 & 313 & 401 & 522 \\
\hline $\mathrm{MgO}_{7}$ & 198 & 242 & 430 & 429 & 483 \\
\hline $\mathrm{MgO}_{8}$ & 102 & 95 & 249 & 196 & 147 \\
\hline $\mathrm{MgO}_{9}$ & 21 & 21 & 56 & 41 & 23 \\
\hline $\mathrm{MgO}_{10}$ & 3 & 1 & 6 & 5 & 3 \\
\hline
\end{tabular}

The results show that, for $\mathrm{N}=2000$ atoms, the number of structural units of $\mathrm{SiO}_{\mathrm{x}}$ is $\mathrm{SiO}_{4}, \mathrm{SiO}_{5}, \mathrm{SiO}_{6}$, and $\mathrm{MgO}_{\mathrm{x}}$ are $\mathrm{MgO}_{3}, \mathrm{MgO}_{4}, \mathrm{MgO}_{5}, \mathrm{MgO}_{6}, \mathrm{MgO}_{7}, \mathrm{MgO}_{8}, \mathrm{MgO}_{9}, \mathrm{MgO}_{10}, \mathrm{MgO}_{11}, \mathrm{MgO}_{12}$ (Figure 4). Angle distribution of $\mathrm{SiO}_{4}$, $\mathrm{SiO}_{5}, \mathrm{SiO}_{6}$ là $100^{\circ}, 90^{\circ}, 85^{\circ}$ and $\mathrm{MgO}_{4}, \mathrm{MgO}_{5}, \mathrm{MgO}_{6}, \mathrm{MgO}_{7}, \mathrm{MgO}_{8}, \mathrm{MgO}_{9}, \mathrm{MgO}_{10}$ is $90^{\circ}, 90^{\circ}, 85^{\circ}, 60^{\circ}, 60^{\circ}, 60^{\circ}$, 
$60^{0}$. The density of structural units of $\mathrm{SiO}_{4}, \mathrm{SiO}_{5}, \mathrm{SiO}_{6}, \mathrm{MgO}_{4}, \mathrm{MgO}_{5}, \mathrm{MgO}_{6}, \mathrm{MgO}_{7}, \mathrm{MgO}_{8}, \mathrm{MgO}_{9}, \mathrm{MgO}_{10}$ is 14 , $325,470,7,58,141,198,102,21,3$. When increasing atomic number $\mathrm{N}$, from $\mathrm{N}=2000$ atoms to $\mathrm{N}=3000$ atoms, 4000 atoms, 5000 atoms, 6000 atoms, the angle distribution of $\mathrm{SiO}_{5}, \mathrm{MgO}_{7}, \mathrm{MgO}_{8}$ is constant and the angle of $\mathrm{SiO}_{4}$, $\mathrm{SiO}_{6}, \mathrm{MgO}_{4}, \mathrm{MgO}_{5}, \mathrm{MgO}_{6}, \mathrm{MgO}_{9}, \mathrm{MgO}_{10}$ has no significant change (Table 4a, Table 4b). The obtained results were consistent with the results (Lee et al., 2005) and showed the influence of $\mathrm{N}$ on structural characteristics such as $\mathrm{r}, \mathrm{g}(\mathrm{r})$, number of structural units, number of density of structural units, coordination number, density of coordination number and 1 is proportional to $\mathrm{N}^{-1 / 3}$ and $\mathrm{E}$ is proportional to $\mathrm{N}^{-1}$.

\subsection{Influence of Temperature}

$\mathrm{MgSiO}_{3}$ bulk 5000 atoms, using visualization method at temperature $\mathrm{T}=300 \mathrm{~K}$, the result of structural shape and transition temperature is shown in Figure 5, radial distribution function in Figure 6.
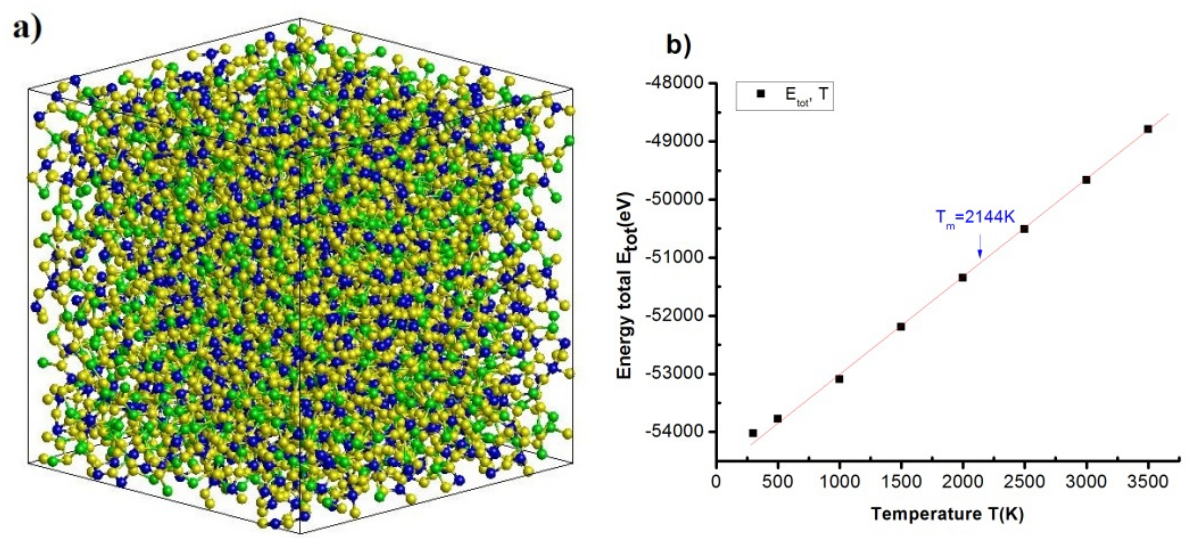

Figure 5. The structural shape of $\mathrm{MgSiO}_{3}$ bulk 5000 atoms at temperature $300 \mathrm{~K}$ (Figure a), phase transition temperature of $\mathrm{MgSiO}_{3}$ bulk model with 5000 atoms at different temperatures (Figure b)

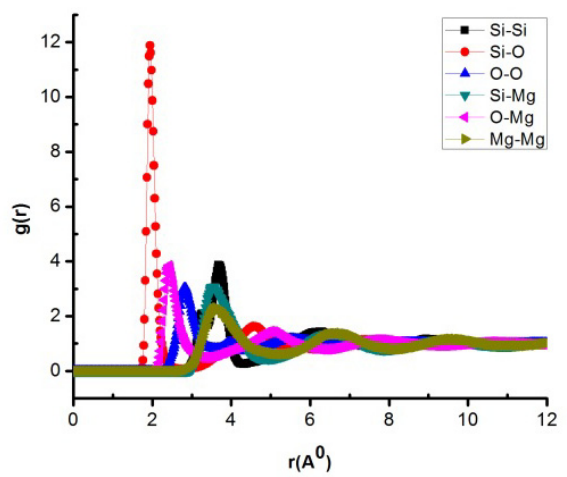

Figure 6. The radial distribution function of links $\mathrm{Si}-\mathrm{Si}$, Si-O, O-O, Si-Mg, O-Mg, Mg-Mg at temperature 300K

Table 5a. The bond length of Si-Si, Si-O, O-O, Si-Mg, O-Mg, Mg-Mg at different temperature

\begin{tabular}{|c|c|c|c|c|c|c|}
\hline \multirow{2}{*}{ Temperature (K) } & \multicolumn{6}{|l|}{$\mathrm{r}_{\mathrm{ij}}(\AA)$} \\
\hline & $\mathrm{Si}-\mathrm{Si}$ & Si-O & $\mathrm{O}-\mathrm{O}$ & Si-Mg & $\mathrm{O}-\mathrm{Mg}$ & $\mathrm{Mg}-\mathrm{Mg}$ \\
\hline 300 & 3.68 & 1.94 & 2.84 & 3.56 & 2.42 & 3.6 \\
\hline 500 & 3.7 & 1.94 & 2.84 & 3.54 & 2.42 & 3.64 \\
\hline 1000 & 3.72 & 1.92 & 2.84 & 3.62 & 2.42 & 3.8 \\
\hline 1500 & 3.66 & 1.88 & 2.88 & 3.72 & 2.4 & 3.94 \\
\hline 2000 & 3.62 & 1.88 & 2.88 & 3.76 & 2.34 & 3.8 \\
\hline 2500 & 3.64 & 1.86 & 2.94 & 3.8 & 2.36 & 3.84 \\
\hline 3000 & 3.58 & 1.86 & 2.9 & 3.78 & 2.3 & 3.92 \\
\hline 3500 & 3.6 & 1.82 & 3 & 3.82 & 2.26 & 4.1 \\
\hline
\end{tabular}


Table 5b. The height of the radial distribution function of links Si-Si, Si-O, O-O, Si-Mg, O-Mg, Mg-Mg at different temperatures

\begin{tabular}{|c|c|c|c|c|c|c|}
\hline \multirow{2}{*}{ Temperature (K) } & \multicolumn{6}{|l|}{$\mathrm{g}_{\mathrm{ij}}(\mathrm{r})$} \\
\hline & $\mathrm{Si}-\mathrm{Si}$ & $\mathrm{Si}-\mathrm{O}$ & $\mathrm{O}-\mathrm{O}$ & $\mathrm{Si}-\mathrm{Mg}$ & $\mathrm{O}-\mathrm{Mg}$ & $\mathrm{Mg}-\mathrm{Mg}$ \\
\hline 300 & 3.87 & 11.88 & 3.03 & 3.07 & 3.85 & 2.3 \\
\hline 500 & 3.71 & 10.65 & 2.89 & 2.97 & 3.4 & 2.29 \\
\hline 1000 & 3.37 & 8.91 & 2.56 & 2.76 & 2.71 & 1.98 \\
\hline 1500 & 3.03 & 8.73 & 2.19 & 2.48 & 2.48 & 1.68 \\
\hline 2000 & 2.83 & 8.5 & 2.06 & 2.29 & 2.32 & 1.52 \\
\hline 2500 & 2.73 & 8.52 & 1.98 & 2.12 & 2.27 & 1.44 \\
\hline 3000 & 2.63 & 8.67 & 1.97 & 2.06 & 2.25 & 1.38 \\
\hline 3500 & 2.7 & 8.79 & 1.97 & 1.98 & 2.25 & 1.34 \\
\hline
\end{tabular}

The results show that $\mathrm{MgSiO}_{3}$ bulk model with 5000 atoms at temperature $\mathrm{T}=300 \mathrm{~K}$ have cube-shaped (Figure $5 \mathrm{a}$ ), size $\mathrm{l}=4.236 \mathrm{~nm}$, energy $\mathrm{E}=-70306.32 \mathrm{eV}$. When $\mathrm{T}$ increases, from $\mathrm{T}=300 \mathrm{~K}$ to $\mathrm{T}=500 \mathrm{~K}, 1000 \mathrm{~K}, 1500 \mathrm{~K}, 2000 \mathrm{~K}$, $2500 \mathrm{~K}, 3000 \mathrm{~K}, 3500 \mathrm{~K}, 1$ increases from $\mathrm{l}=4.236 \mathrm{~nm}$ to $1=4.348 \mathrm{~nm}, 4.398 \mathrm{~nm}, 4.583 \mathrm{~nm}, 4.731 \mathrm{~nm}, 4.884 \mathrm{~nm}$, $5.071 \mathrm{~nm}, 5.257 \mathrm{~nm}$ and $\mathrm{E}$ increases leads to a phase transition temperature $\left(\mathrm{T}_{\mathrm{m}}\right), \mathrm{T}_{\mathrm{m}}=2144 \mathrm{~K}$ (Figure $5 \mathrm{~b}$ ). This result is consistent with the empirical results (Kohara et al., 2004). The results show that, at temperature $\mathrm{T}=300 \mathrm{~K}$, the first peak of links Si-Si, Si-O, O-O, Si-Mg, O-Mg, Mg-Mg of the radial distribution function is dominant and the bonding length is $3.68 \AA, 1.94 \AA, 2.84 \AA, 3.56 \AA, 2.42 \AA, 3.6 \AA$ (Figure 6, Table 5a). When increasing the temperature $(\mathrm{T})$, from $\mathrm{T}=300 \mathrm{~K}$ to $\mathrm{T}=500 \mathrm{~K}, 1000 \mathrm{~K}, 1500 \mathrm{~K}, 2000 \mathrm{~K}, 2500 \mathrm{~K}, 3000 \mathrm{~K}, 3500 \mathrm{~K}$, the first peak position of the links was not changed significantly (Table 5a), and g(r) decreased sharply (Table 5b). Combined with the above results, the increase in temperature leads to E, 1 increase and atomic density decrease. This shows that the internal molecular distance between the links does not depend on temperature leading to the non-existence of distant order but there is always the existence of close order. In order to confirm the accuracy of the results, research the coordination number, the density of coordination number of the links and the results are shown in Figure 7.

a)

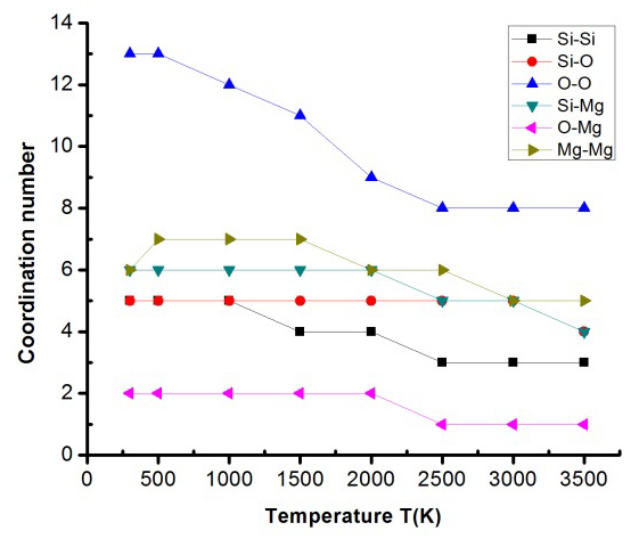

b)

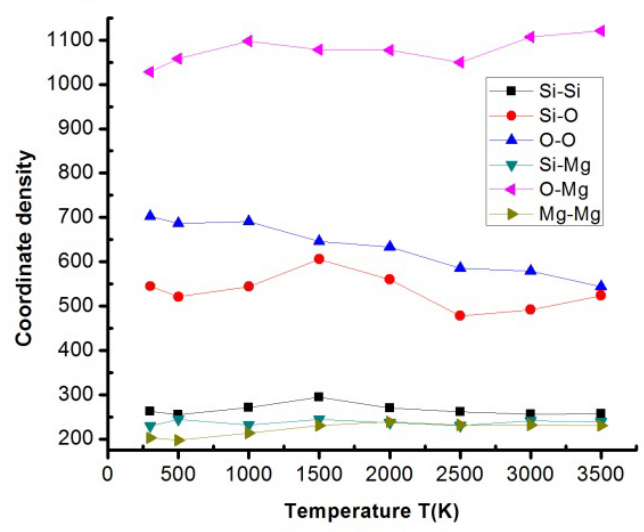

Figure 7. The coordination number (Figure a), coordination number density (Figure b) at different temperatures

The results show that $\mathrm{MgSiO}_{3}$ bulk model with 5000 atoms at temperature $\mathrm{T}=300 \mathrm{~K}$ has a coordination number of links Si-Si, Si-O, O-O, Si-Mg, O-Mg, Mg-Mg is 5, 5, 13, 6, 2, 6. When increasing $\mathrm{T}$ from $\mathrm{T}=300 \mathrm{~K}$ to $\mathrm{T}=500 \mathrm{~K}, 1000 \mathrm{~K}, 1500 \mathrm{~K}, 2000 \mathrm{~K}, 2500 \mathrm{~K}, 3000 \mathrm{~K}, 3500 \mathrm{~K}$, the coordination number of the links $\mathrm{Si}-\mathrm{Si}, \mathrm{Si}-\mathrm{O}, \mathrm{O}-\mathrm{O}, \mathrm{Si}-\mathrm{Mg}, \mathrm{O}-\mathrm{Mg}, \mathrm{Mg}-\mathrm{Mg}$ has a large change value (Figure 7a). The coordination number-density of the links $\mathrm{Si}-\mathrm{Si}, \mathrm{Si}-\mathrm{O}, \mathrm{O}-\mathrm{O}, \mathrm{Si}-\mathrm{Mg}, \mathrm{O}-\mathrm{Mg}, \mathrm{Mg}-\mathrm{Mg}$ has negligible value changes (Figure 7b). The main cause of the changes link and density of coordination number is due to the heterogeneity in the sample: When the temperature increases, $1, \mathrm{E}$ increases of and the length of links Si-Si, Si-O, O-O, $\mathrm{Si}-\mathrm{Mg}, \mathrm{O}-\mathrm{Mg}, \mathrm{Mg}-\mathrm{Mg}$ changes lead to structural change. Next, studying structural unit number $\mathrm{SiO}_{\mathrm{x}}$, $\mathrm{MgO}_{\mathrm{x}}$ in $\mathrm{MgSiO}_{3}$ bulk model with 5000 atoms, the results are shown in Table 6. 
Table 6a. Number of structural units $\mathrm{SiO}_{\mathrm{x}}, \mathrm{MgO}_{\mathrm{x}}$ of $\mathrm{MgSiO}_{3}$ bulk model with 5000 atoms at different temperatures

\begin{tabular}{lllllllll}
\hline Temperature (K) & 300 & 500 & 1000 & 1500 & 2000 & 2500 & 3000 & 3500 \\
\hline $\mathrm{SiO}_{4}$ (degrees) & 105 & 105 & 105 & 105 & 100 & 100 & 100 & 100 \\
$\mathrm{SiO}_{5}$ (degrees) & 90 & 90 & 90 & 90 & 90 & 90 & 90 & 90 \\
$\mathrm{SiO}_{6}$ (degrees) & 90 & 90 & 85 & 85 & 85 & 80 & 85 & 80 \\
$\mathrm{MgO}_{3}$ (degrees) & 0 & 95 & 0 & 105 & 95 & 105 & 100 & 100 \\
$\mathrm{MgO}_{4}$ (degrees) & 95 & 95 & 100 & 95 & 95 & 95 & 95 & 100 \\
$\mathrm{MgO}_{5}$ (degrees) & 90 & 90 & 90 & 95 & 90 & 90 & 60 & 60 \\
$\mathrm{MgO}_{6}$ (degrees) & 60 & 60 & 60 & 60 & 60 & 60 & 60 & 60 \\
$\mathrm{MgO}_{7}$ (degrees) & 60 & 60 & 60 & 60 & 55 & 60 & 60 & 55 \\
$\mathrm{MgO}_{8}$ (degrees) & 60 & 60 & 55 & 55 & 55 & 60 & 55 & 55 \\
$\mathrm{MgO}_{9}$ (degrees) & 60 & 50 & 55 & 55 & 55 & 55 & 55 & 55 \\
$\mathrm{MgO}_{10}$ (degrees) & 55 & 50 & 55 & 55 & 55 & 0 & 0 & 0 \\
\hline
\end{tabular}

Table 6b. Number of structural units $\mathrm{SiO}_{\mathrm{x}}, \mathrm{MgO}_{\mathrm{x}}$ of $\mathrm{MgSiO}_{3}$ bulk model with 5000 atoms at different temperatures

\begin{tabular}{lllllllll}
\hline Temperature (K) & 300 & 500 & 1000 & 1500 & 2000 & 2500 & 3000 & 3500 \\
\hline $\mathrm{SiO}_{4}$ & 46 & 40 & 42 & 155 & 237 & 285 & 309 & 306 \\
$\mathrm{SiO}_{5}$ & 840 & 765 & 709 & 676 & 563 & 434 & 347 & 288 \\
$\mathrm{SiO}_{6}$ & 1016 & 1022 & 834 & 340 & 178 & 127 & 87 & 70 \\
$\mathrm{MgO}_{3}$ & 0 & 1 & 0 & 5 & 10 & 29 & 33 & 33 \\
$\mathrm{MgO}_{4}$ & 33 & 23 & 16 & 49 & 70 & 109 & 105 & 93 \\
$\mathrm{MgO}_{5}$ & 202 & 157 & 110 & 165 & 172 & 162 & 145 & 133 \\
$\mathrm{MgO}_{6}$ & 401 & 351 & 282 & 276 & 235 & 140 & 120 & 116 \\
$\mathrm{MgO}_{7}$ & 429 & 447 & 418 & 250 & 171 & 64 & 56 & 58 \\
$\mathrm{MgO}_{8}$ & 195 & 237 & 328 & 129 & 73 & 16 & 15 & 20 \\
$\mathrm{MgO}_{9}$ & 40 & 80 & 132 & 39 & 18 & 3 & 3 & 4 \\
$\mathrm{MgO}_{10}$ & 5 & 10 & 28 & 7 & 3 & 0 & 0 & 0 \\
\hline
\end{tabular}

The results show that, $\mathrm{MgSiO}_{3}$ bulk model with 5000 atoms at temperature $\mathrm{T}=300 \mathrm{~K}$ has structural units is $\mathrm{SiO}_{4}$, $\mathrm{SiO}_{5}, \mathrm{SiO}_{6}, \mathrm{MgO}_{4}, \mathrm{MgO}_{5}, \mathrm{MgO}_{6}, \mathrm{MgO}_{7}, \mathrm{MgO}_{8}, \mathrm{MgO}_{9}, \mathrm{MgO}_{10}$ with an angle distribution of $105^{\circ}, 90^{\circ}, 90^{\circ}, 95^{\circ}, 90^{\circ}$, $60^{\circ}, 60^{\circ}, 60^{\circ}, 60^{\circ}, 55^{\circ}$ and a density of structural units is $46,840,1016,33,202,401,429,195,40,5$. When temperature $\mathrm{T}$ is increased, from $\mathrm{T}=300 \mathrm{~K}$ to $\mathrm{T}=500 \mathrm{~K}, 1000 \mathrm{~K}, 1500 \mathrm{~K}, 2000 \mathrm{~K}, 2500 \mathrm{~K}, 3000 \mathrm{~K}, 3500 \mathrm{~K}, \mathrm{SiO}_{5}, \mathrm{MgO}_{6}$ have a constant value of $90^{\circ}, 60^{\circ}$, other angle distributions and number density of structural unit has change value as $\mathrm{MgO}_{3}$ appears at $\mathrm{T}=500 \mathrm{~K}$, disappears at $\mathrm{T}=1000 \mathrm{~K}$ and stabilizes at $1500 \mathrm{~K} ; \mathrm{MgO}_{10}$ disappears at $\mathrm{T}=2500 \mathrm{~K}$ and $\mathrm{SiO}_{4}, \mathrm{MgO}_{4}, \mathrm{MgO}_{5}, \mathrm{MgO}_{6}, \mathrm{MgO}_{7}, \mathrm{MgO}_{8}, \mathrm{MgO}_{9}$ have a variable angle distribution and the densities of angle distribution changed (Table $6 \mathrm{a}$, Table $6 \mathrm{~b}$ ). With the disappearance of $\mathrm{MgO}_{10}$ at $\mathrm{T}=2500 \mathrm{~K}$, it raises the question of whether this is a phase transition temperature or not. The results show that in the temperature range from $\mathrm{T}=2000 \mathrm{~K}$ to $\mathrm{T}=2500 \mathrm{~K}$ the number of structural units of $\mathrm{SiO}_{4}, \mathrm{SiO}_{5}, \mathrm{MgO}_{4}, \mathrm{MgO}_{5}, \mathrm{MgO}_{6}, \mathrm{MgO}_{7}, \mathrm{MgO}_{8}, \mathrm{MgO}_{9}, \mathrm{MgO}_{10}$ has a big change, leading to the disappearance of structure units $\mathrm{MgO}_{10}$. To answer the above questions, continue to study the structure at temperatures $300 \mathrm{~K}, 2000 \mathrm{~K}$ with different pressure values.

\subsection{Effect of Pressure}

\subsubsection{Effect of Pressure at Temperature $300 \mathrm{~K}$}

$\mathrm{MgSiO}_{3}$ bulk model with 5000 atoms at temperature $\mathrm{T}=300 \mathrm{~K}$ with pressure $\mathrm{P}=0 \mathrm{GPa}, 20 \mathrm{GPa}, 40 \mathrm{GPa}, 60 \mathrm{GPa}$, $80 \mathrm{GPa}, 100 \mathrm{GPa}$, results are shown in Figure 8. 

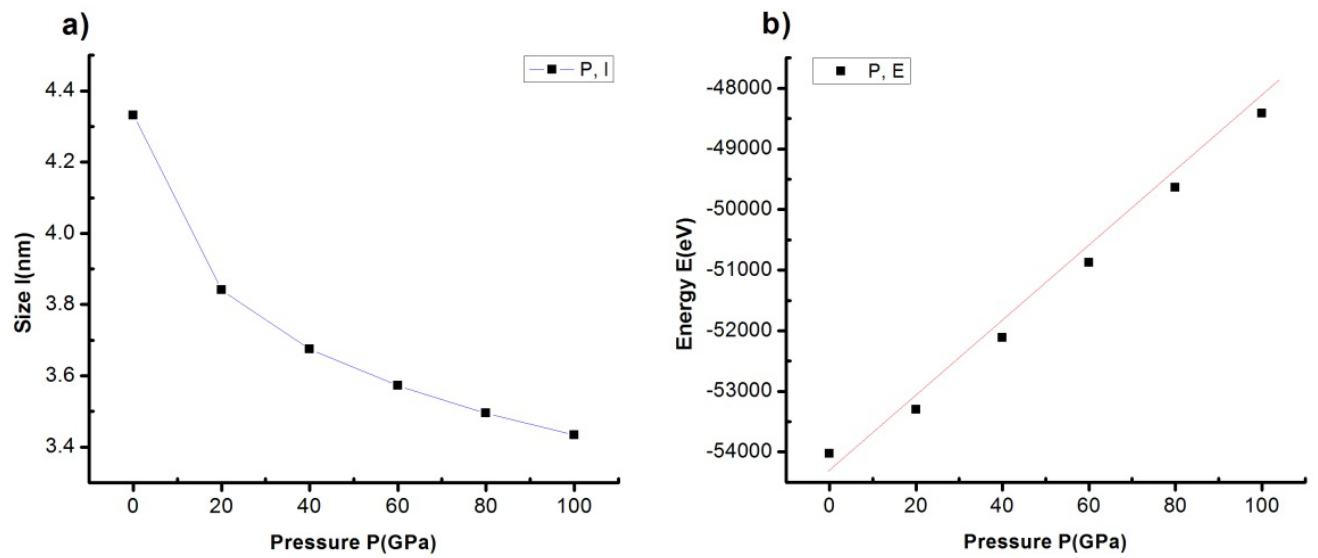

Figure 8. The relationship between pressure, size (Figure a), pressure, energy (Figure b) of $\mathrm{MgSiO}_{3}$ bulk at temperature $300 \mathrm{~K}$

The results show that, $\mathrm{MgSiO}_{3}$ bulk model with 5000 atoms at pressure $\mathrm{P}=0 \mathrm{GPa}$ has size $1=4.332 \mathrm{~nm}$, energy $\mathrm{E}=-54028.51 \mathrm{eV}$. When increasing $\mathrm{P}$ from $\mathrm{P}=0 \mathrm{GPa}$ to $\mathrm{P}=20 \mathrm{GPa}, 40 \mathrm{GPa}, 60 \mathrm{GPa}, 80 \mathrm{GPa}, 100 \mathrm{GPa}$ leading to 1 decreases from $\mathrm{l}=4.332 \mathrm{~nm}$ to $3.434 \mathrm{~nm}$ (Figure 8a) and $\mathrm{E}$ increases from $\mathrm{E}=-54028.51 \mathrm{eV}$ to $-48415.37 \mathrm{eV}$ (Figure $8 \mathrm{~b})$. To confirm this, study structure of the links Si-Si, Si-O, O-O, Si-Mg, O-Mg, Mg-Mg, the results are shown in Figure 9.
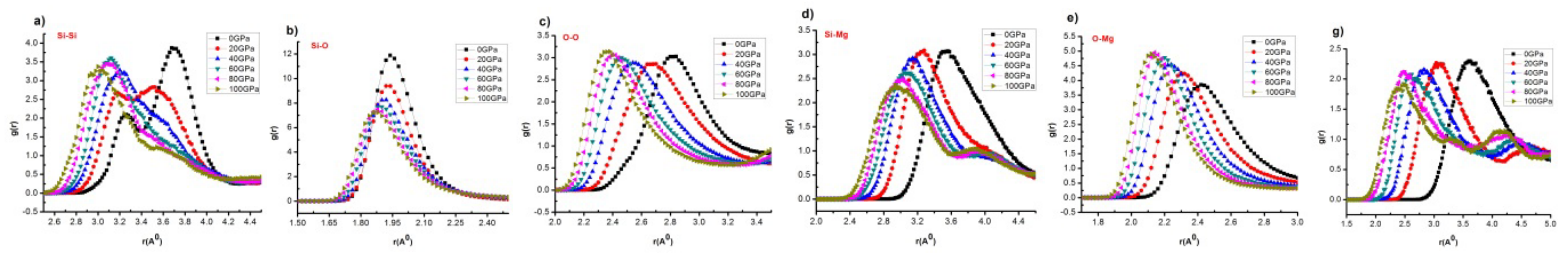

Figure 9. The radial distribution function of links $\mathrm{Si}-\mathrm{Si}, \mathrm{Si}-\mathrm{O}, \mathrm{O}-\mathrm{O}, \mathrm{Si}-\mathrm{Mg}, \mathrm{O}-\mathrm{Mg}, \mathrm{Mg}-\mathrm{Mg}$ at temperature $300 \mathrm{~K}$ with different pressures

The results show that $\mathrm{MgSiO}_{3}$ bulk model with 5000 atoms at pressure $\mathrm{P}=0 \mathrm{GPa}$, temperature $\mathrm{T}=300 \mathrm{~K}$ has the first pick position of $R D F$ is $r=3.68 \AA$, the height of $R D F$ is $g(r)=3.87$. When increasing $P$, from $P=0 \mathrm{GPa}$ to $\mathrm{P}=20 \mathrm{GPa}$, $40 \mathrm{GPa}, 60 \mathrm{GPa}, 80 \mathrm{GPa}, 100 \mathrm{GPa}$, the first peak position of RDF gradually shifted to left and height $\mathrm{g}(\mathrm{r})$ increased with links O-Mg, Si-Si and reduced with links Si-O, O-O, Si-Mg, Mg-Mg (Figure 9). To confirm this, study the coordination number and the density of coordination number, results are shown in Figure 10.
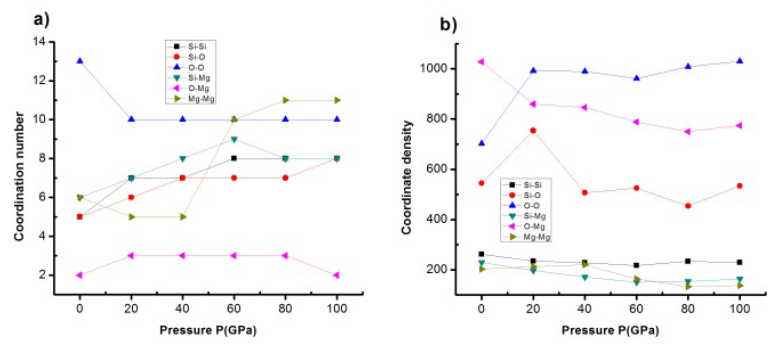

Figure 10. The coordination number (Figure a), the density of coordination number (Figure b) at different pressures

The results show that $\mathrm{MgSiO}_{3}$ bulk model with 5000 atoms at temperature $\mathrm{T}=300 \mathrm{~K}$ with pressure $\mathrm{P}=0 \mathrm{GPa}$ has a coordination number of links Si-Si, Si-O, O-O, Si-Mg, O-Mg, Mg-Mg is 5, 5, 13, 6, 2, 6. When increasing P from $\mathrm{P}=0 \mathrm{GPa}$ to $\mathrm{P}=20 \mathrm{GPa}, 40 \mathrm{GPa}, 60 \mathrm{GPa}, 80 \mathrm{GPa}, 100 \mathrm{GPa}$, the coordination number of the links Si-Si, Si-O, O-O, $\mathrm{Si}-\mathrm{Mg}, \mathrm{O}-\mathrm{Mg}, \mathrm{Mg}-\mathrm{Mg}$ has great change value (Figure 10a). The density of coordination number of links $\mathrm{Si}-\mathrm{Si}$, 
$\mathrm{Si}-\mathrm{Mg}, \mathrm{Mg}-\mathrm{Mg}$ has changed insignificantly, while the density of coordination number of links O-O, Si-O, O-Mg have great change value (Figure 10b). The reason for the change of links, coordination number and density of coordination number are the heterogeneity in sample, because: increasing $\mathrm{P}$ leads to size 1 decreases, increasing energy $\mathrm{E}$ and the linking length of $\mathrm{Si}-\mathrm{Si}, \mathrm{Si}-\mathrm{O}, \mathrm{O}-\mathrm{O}, \mathrm{Si}-\mathrm{Mg}, \mathrm{O}-\mathrm{Mg}, \mathrm{Mg}-\mathrm{Mg}$ changes leading to structural changes. Next, studying the number of structural units, the density of structural units of $\mathrm{SiO}_{\mathrm{x}}, \mathrm{MgO}_{\mathrm{x}}$, the results are shown in Table $7 \mathrm{a}$ and Table $7 \mathrm{~b}$.

Table 7a. The number of structural unit $\mathrm{SiO}_{\mathrm{x}}, \mathrm{MgO}_{\mathrm{x}}$ of $\mathrm{MgSiO}_{3}$ bulk model with 5000 atoms at temperature $300 \mathrm{~K}$ with different pressures

\begin{tabular}{lllllll}
\hline Pressures (GPa) & 0 & 20 & 40 & 60 & 80 & 100 \\
\hline $\mathrm{SiO}_{4}$ (degrees) & 105 & 0 & 0 & 0 & 0 & 0 \\
$\mathrm{SiO}_{5}$ (degrees) & 90 & 85 & 85 & 0 & 0 & 0 \\
$\mathrm{SiO}_{6}$ (degrees) & 90 & 85 & 85 & 80 & 80 & 80 \\
$\mathrm{MgO}_{3}$ (degrees) & 0 & 0 & 0 & 0 & 0 & 0 \\
$\mathrm{MgO}_{4}$ (degrees) & 95 & 0 & 0 & 0 & 0 & 0 \\
$\mathrm{MgO}_{5}$ (degrees) & 90 & 85 & 0 & 0 & 0 & 0 \\
$\mathrm{MgO}_{6}$ (degrees) & 60 & 80 & 75 & 75 & 85 & 75 \\
$\mathrm{MgO}_{7}$ (degrees) & 60 & 65 & 70 & 70 & 70 & 70 \\
$\mathrm{MgO}_{8}$ (degrees) & 60 & 65 & 65 & 65 & 65 & 65 \\
$\mathrm{MgO}_{9}$ (degrees) & 55 & 65 & 65 & 65 & 65 & 65 \\
$\mathrm{MgO}_{10}$ (degrees) & 55 & 60 & 60 & 60 & 60 & 60 \\
$\mathrm{MgO}_{11}$ (degrees) & 0 & 60 & 55 & 60 & 60 & 60 \\
$\mathrm{MgO}_{12}$ (degrees) & 0 & 55 & 55 & 55 & 0 & 50 \\
\hline
\end{tabular}

Table $7 \mathrm{~b}$. The density of structural unit $\mathrm{SiO}_{\mathrm{x}}, \mathrm{MgO}_{\mathrm{x}}$ of $\mathrm{MgSiO}_{3}$ bulk model with 5000 atoms at temperature $300 \mathrm{~K}$ with different pressures

\begin{tabular}{lllllll}
\hline Pressures (GPa) & 0 & 20 & 40 & 60 & 80 & 100 \\
\hline $\mathrm{SiO}_{4}$ & 46 & 0 & 0 & 0 & 0 & 0 \\
$\mathrm{SiO}_{5}$ & 840 & 40 & 4 & 0 & 0 & 0 \\
$\mathrm{SiO}_{6}$ & 1016 & 1691 & 692 & 362 & 166 & 73 \\
$\mathrm{MgO}_{3}$ & 0 & 0 & 0 & 0 & 0 & 0 \\
$\mathrm{MgO}_{4}$ & 33 & 0 & 0 & 0 & 0 & 0 \\
$\mathrm{MgO}_{5}$ & 202 & 2 & 0 & 0 & 0 & 0 \\
$\mathrm{MgO}_{6}$ & 401 & 46 & 22 & 6 & 9 & 7 \\
$\mathrm{MgO}_{7}$ & 429 & 349 & 285 & 166 & 215 & 142 \\
$\mathrm{MgO}_{8}$ & 195 & 905 & 998 & 876 & 989 & 899 \\
$\mathrm{MgO}_{9}$ & 41 & 891 & 1023 & 1317 & 1242 & 1301 \\
$\mathrm{MgO}_{10}$ & 5 & 298 & 419 & 580 & 532 & 680 \\
$\mathrm{MgO}_{11}$ & 0 & 32 & 81 & 91 & 86 & 102 \\
$\mathrm{MgO}_{12}$ & 0 & 2 & 2 & 8 & 0 & 5 \\
\hline
\end{tabular}

The result show that $\mathrm{MgSiO}_{3}$ bulk model with 5000 atoms at temperature $\mathrm{T}=300 \mathrm{~K}$, pressure $\mathrm{P}=0 \mathrm{GPa}$ has structural units are $\mathrm{SiO}_{4}, \mathrm{SiO}_{5}, \mathrm{SiO}_{6}, \mathrm{MgO}_{3}, \mathrm{MgO}_{4}, \mathrm{MgO}_{5}, \mathrm{MgO}_{6}, \mathrm{MgO}_{7}, \mathrm{MgO}_{8}, \mathrm{MgO}_{9}, \mathrm{MgO}_{10}, \mathrm{MgO}_{11}, \mathrm{MgO}_{12}$ corresponding to the angle distribution of $105^{\circ}, 90^{\circ}, 90^{\circ}, 0^{\circ}, 95^{\circ}, 90^{\circ}, 60^{\circ}, 60^{\circ}, 60^{\circ}, 60^{\circ}, 55^{0}, 55^{\circ}, 0^{\circ}, 0^{\circ}$. When increasing $\mathrm{P}$, from $\mathrm{P}=0 \mathrm{GPa}$ to $\mathrm{P}=20 \mathrm{GPa}, 40 \mathrm{GPa}, 60 \mathrm{GPa}, 80 \mathrm{GPa}, 100 \mathrm{GPa}$ leading to angle distribution and the number density of structural unit $\mathrm{SiO}_{4}, \mathrm{SiO}_{5}, \mathrm{SiO}_{6}, \mathrm{MgO}_{3}, \mathrm{MgO}_{4}, \mathrm{MgO}_{5}, \mathrm{MgO}_{6}, \mathrm{MgO}_{7}, \mathrm{MgO}_{8}, \mathrm{MgO}_{9}, \mathrm{MgO}_{10}$, $\mathrm{MgO}_{11}, \mathrm{MgO}_{12}$ has a very large change as $\mathrm{SiO}_{4}, \mathrm{MgO}_{4}$ disappear at $\mathrm{P}=20 \mathrm{GPa} ; \mathrm{MgO}_{11}, \mathrm{MgO}_{12}$ appear at $\mathrm{P}=20 \mathrm{GPa}$ and angle distribution of $\mathrm{SiO}_{5}, \mathrm{MgO}_{5}$ decrease at $\mathrm{P}=20 \mathrm{GPa} ; \mathrm{SiO}_{5}$ disappears at $\mathrm{P}=60 \mathrm{GPa}$; angle distribution $\mathrm{SiO}_{6}$ decreases at $\mathrm{P}=20 \mathrm{GPa}$ and angle distributions $\mathrm{MgO}_{8}, \mathrm{MgO}_{9}, \mathrm{MgO}_{10}$ increase at $\mathrm{P}=20 \mathrm{GPa}$ (Table $7 \mathrm{a}$ ) and changes in the density of structural units are very big (Table 7b).

\subsubsection{Effect of Pressure at Temperature 2000K}

$\mathrm{MgSiO}_{3}$ bulk model with 5000 atoms at temperature $\mathrm{T}=2000 \mathrm{~K}$ with pressure $\mathrm{P}=0 \mathrm{GPa}, 20 \mathrm{GPa}, 40 \mathrm{GPa}, 60 \mathrm{GPa}$, 80GPa, 100GPa, results are shown in Figure 11. 
a)

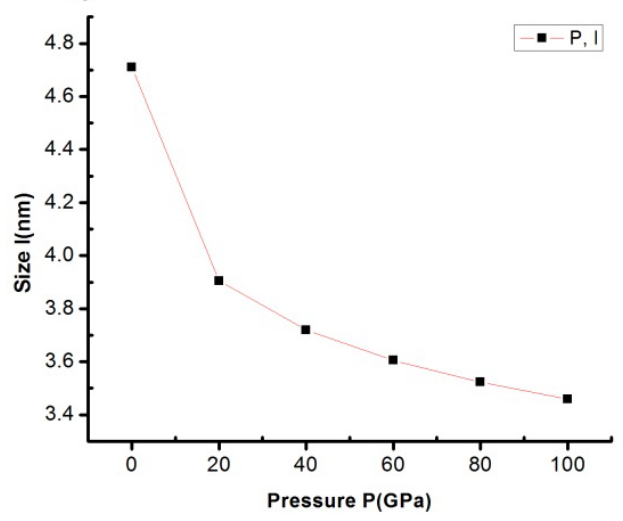

b)

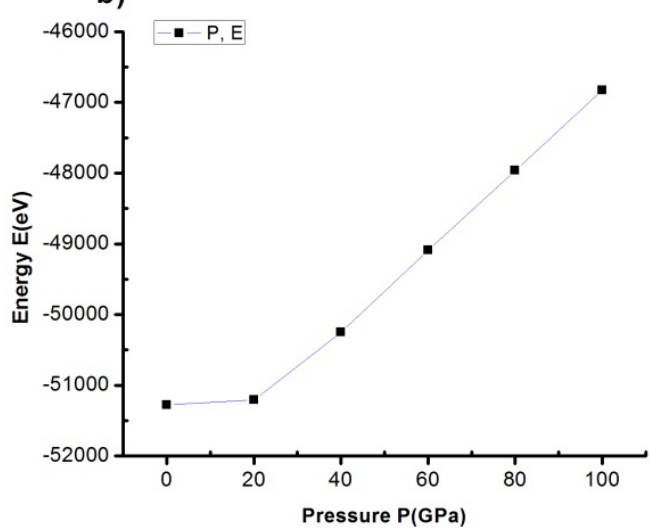

Figure 11. The relationship between pressure and size (Figure a), pressure and energy (Figure b) of $\mathrm{MgSiO}_{3}$ bulk model with at temperature $2000 \mathrm{~K}$ with different pressures

The result show that, $\mathrm{MgSiO}_{3}$ bulk model with 5000 atoms at temperature $\mathrm{T}=2000 \mathrm{~K}$ with pressure $\mathrm{P}=0 \mathrm{GPa}$ has size $\mathrm{l}=4.711 \mathrm{~nm}$, energy $\mathrm{E}=-51279.79 \mathrm{eV}$. When increasing $\mathrm{P}$ from $\mathrm{P}=0 \mathrm{GPa}$ to $\mathrm{P}=20 \mathrm{GPa}, 40 \mathrm{GPa}, 60 \mathrm{GPa}, 80 \mathrm{GPa}$, $100 \mathrm{GPa}$ leads to 1 decreases from $1=4.711 \mathrm{~nm}$ to $1=3,458 \mathrm{~nm}$ (Figure $11 \mathrm{a}$ ), $\mathrm{E}$ increases from $\mathrm{E}=-51279.79 \mathrm{eV}$ to $\mathrm{E}=-46823.94 \mathrm{eV}$ (Figure 11b). To confirm this, study the structure of the links Si-Si, Si-O, O-O, Si-Mg, O-Mg, Mg-Mg, results are shown in Table 8a, Table 8b.

Table 8a. The linking length of Si-Si, Si-O, O-O, Si-Mg, O-Mg, Mg-Mg at temperature 2000K with different pressures

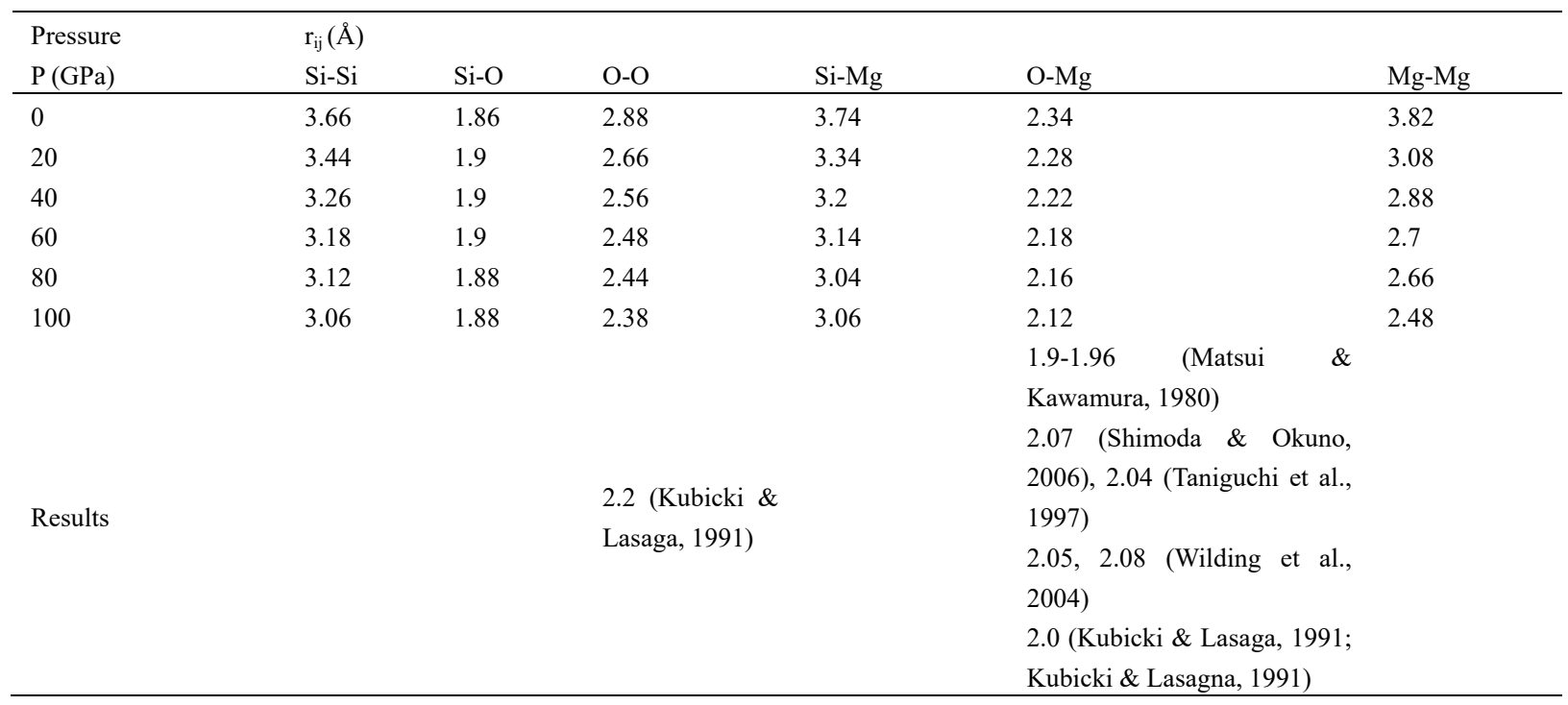

Table $8 \mathrm{~b}$. The height radial distribution function of link $\mathrm{Si}-\mathrm{Si}, \mathrm{Si}-\mathrm{O}, \mathrm{O}-\mathrm{O}, \mathrm{Si}-\mathrm{Mg}, \mathrm{O}-\mathrm{Mg}, \mathrm{Mg}-\mathrm{Mg}$ at temperature 2000K with different pressures

\begin{tabular}{lllllll}
\hline \multirow{2}{*}{ Pressure (GPa) } & $\mathrm{g}_{\mathrm{ij}}(\mathrm{r})$ & & & & & $\mathrm{O}-\mathrm{Mg}$ \\
& $\mathrm{Si}-\mathrm{Si}$ & $\mathrm{Si}-\mathrm{O}$ & $\mathrm{O}-\mathrm{O}$ & $\mathrm{Si}-\mathrm{Mg}$ & 2.32 & 1.56 \\
\hline 0 & 2.89 & 8.31 & 2.05 & 2.18 & 2.7 & 1.85 \\
20 & 2.66 & 5.48 & 2.17 & 2.47 & 3.03 & 1.91 \\
40 & 2.91 & 5.25 & 2.28 & 2.3 & 3.24 & 1.91 \\
60 & 3.06 & 5.08 & 2.38 & 2.25 & 3.43 & 1.98 \\
80 & 3.16 & 5.1 & 2.47 & 2.15 & 3.55 & 1.92 \\
100 & 3.24 & 5.09 & 2.54 & & & \\
\hline
\end{tabular}


The result show that, $\mathrm{MgSiO}_{3}$ bulk model with 5000 atoms at temperature $\mathrm{T}=2000 \mathrm{~K}$ with pressure $\mathrm{P}=0 \mathrm{GPa}$, the first peak position of links Si-Si, Si-O, O-O, Si-Mg, O-Mg, Mg-Mg are r=3.66 $, 1.86 \AA, 2.88 \AA, 3.74 \AA, 2.34 \AA$, $3.82 \AA$ (Table $8 \mathrm{a}$ ) and the height of first peak position of RDF $\mathrm{g}(\mathrm{r})=2.89,8.31,2.05,2.18,2.32,1.56$ (Table 8a). When increasing $\mathrm{P}$, from $\mathrm{P}=0 \mathrm{GPa}$ to $\mathrm{P}=20 \mathrm{GPa}, 40 \mathrm{GPa}, 60 \mathrm{GPa}, 80 \mathrm{GPa}, 100 \mathrm{GPa}$ leads to the first peak position of RDF moves gradually to the left and g(r) increases with links Si-Si, O-O, Si-Mg, O-Mg, Mg-Mg and reduces with link Si-O. The results are consistent with results (Wilding et al., 2004; Taniguchi et al., 1997; Lee et al., 2005; Matsui \& Kawamura, 1980; Kubicki \& Lasagna, 1991; Shimoda \& Okuno, 2006). To confirm this, study the coordination number and the density of coordination number, as shown in Figure 12.
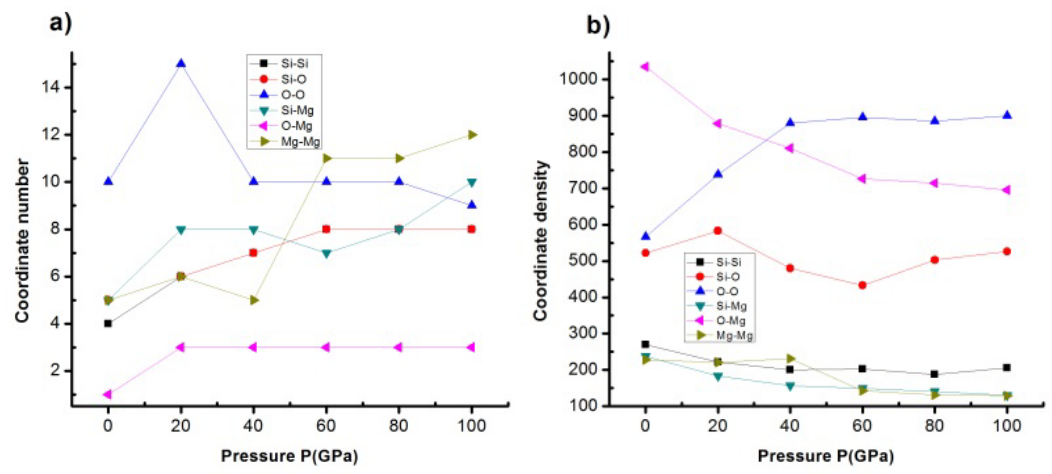

Figure 12. The coordination numbers (Figure a), the coordinate numbers density (Figure b) at temperature $200 \mathrm{~K}$ with different pressures

The result show that, $\mathrm{MgSiO}_{3}$ bulk model with 5000 atoms at temperature $\mathrm{T}=2000 \mathrm{~K}$ with pressure $\mathrm{P}=0 \mathrm{GPa}$ has the coordination numbers of the links Si-Si, Si-O, O-O, Si-Mg, O-Mg, Mg-Mg are 4, 5, 10, 5, 1, 5. When increasing P, from $\mathrm{P}=0 \mathrm{GPa}$ to $\mathrm{P}=20 \mathrm{GPa}, 40 \mathrm{GPa}, 60 \mathrm{GPa}, 80 \mathrm{GPa}, 100 \mathrm{GPa}$ leading to the coordination numbers of the links $\mathrm{Si}-\mathrm{Si}$, $\mathrm{Si}-\mathrm{O}, \mathrm{O}-\mathrm{O}, \mathrm{Si}-\mathrm{Mg}, \mathrm{O}-\mathrm{Mg}, \mathrm{Mg}-\mathrm{Mg}$ have great change value (Figure 12a). The density of coordination numbers of the links $\mathrm{Si}-\mathrm{Si}, \mathrm{Si}-\mathrm{Mg}, \mathrm{Mg}-\mathrm{Mg}$ changes significantly and the density of coordination numbers of links O-O, Si-O, $\mathrm{O}-\mathrm{Mg}, \mathrm{O}-\mathrm{Mg}$ are greatly changed (Figure 12b). The cause of the changes of the links, coordination number and density of coordination numbers is the heterogeneity in the sample, because: When increasing P leads to $1, \mathrm{E}$ increase, length of the links $\mathrm{Si}-\mathrm{Si}, \mathrm{Si}-\mathrm{O}, \mathrm{O}-\mathrm{O}, \mathrm{Si}-\mathrm{Mg}, \mathrm{O}-\mathrm{Mg}, \mathrm{Mg}-\mathrm{Mg}$ changes leading to structural change. Next, study the number of structural units of the links $\mathrm{SiO}_{x}, \mathrm{MgO}_{\mathrm{x}}$, the results are shown in Table 9a and Table $9 \mathrm{~b}$.

Table 9a. The angle distribution of the number of structural units $\mathrm{SiO}_{\mathrm{x}}, \mathrm{MgO}_{\mathrm{x}}$ at temperature $2000 \mathrm{~K}$ with different pressures

\begin{tabular}{lllllll}
\hline Pressure (GPa) & 0 & 20 & 40 & 60 & 80 & 100 \\
\hline $\mathrm{SiO}_{4}$ (degrees) & 100 & 0 & 0 & 0 & 0 & 0 \\
$\mathrm{SiO}_{5}$ (degrees) & 90 & 85 & 85 & 0 & 0 & 0 \\
$\mathrm{SiO}_{6}$ (degrees) & 85 & 85 & 80 & 80 & 85 & 85 \\
$\mathrm{MgO}_{3}$ (degrees) & 100 & 0 & 0 & 0 & 0 & 0 \\
$\mathrm{MgO}_{4}$ (degrees) & 95 & 0 & 0 & 0 & 0 & 0 \\
$\mathrm{MgO}_{5}$ (degrees) & 65 & 0 & 0 & 0 & 0 & 0 \\
$\mathrm{MgO}_{6}$ (degrees) & 60 & 80 & 75 & 75 & 75 & 70 \\
$\mathrm{MgO}_{7}$ (degrees) & 60 & 70 & 70 & 70 & 70 & 70 \\
$\mathrm{MgO}_{8}$ (degrees) & 60 & 65 & 65 & 65 & 65 & 65 \\
$\mathrm{MgO}_{9}$ (degrees) & 55 & 60 & 65 & 65 & 65 & 65 \\
$\mathrm{MgO}_{10}$ (degrees) & 0 & 60 & 60 & 60 & 60 & 60 \\
$\mathrm{MgO}_{11}$ (degrees) & 0 & 55 & 55 & 55 & 55 & 55 \\
$\mathrm{MgO}_{12}$ (degrees) & 0 & 55 & 55 & 55 & 55 & 55 \\
\hline
\end{tabular}

The results show that $\mathrm{MgSiO}_{3}$ bulk model with 5000 atom at temperature $\mathrm{T}=2000 \mathrm{~K}$ with pressure $\mathrm{P}=0 \mathrm{GPa}$ has structural units are $\mathrm{SiO}_{4}, \mathrm{SiO}_{5}, \mathrm{SiO}_{6}, \mathrm{MgO}_{3}, \mathrm{MgO}_{4}, \mathrm{MgO}_{5}, \mathrm{MgO}_{6}, \mathrm{MgO}_{7}, \mathrm{MgO}_{8}, \mathrm{MgO}_{9}, \mathrm{MgO}_{10}, \mathrm{MgO}_{11}, \mathrm{MgO}_{12}$ 
corresponding to the angle distribution of $105^{\circ}, 90^{\circ}, 85^{\circ}, 100^{\circ}, 95^{\circ}, 65^{\circ}, 60^{\circ}, 60^{\circ}, 60^{\circ}, 55^{\circ}, 0^{\circ}, 0^{\circ}, 0^{\circ}$. When increasing $\mathrm{P}$, from $\mathrm{P}=0 \mathrm{GPa}$ to $\mathrm{P}=20 \mathrm{GPa}, 40 \mathrm{GPa}, 60 \mathrm{GPa}, 80 \mathrm{GPa}, 100 \mathrm{GPa}$ leading to $\mathrm{SiO}_{4}, \mathrm{SiO}_{5}, \mathrm{SiO}_{6}, \mathrm{MgO}_{3}$, $\mathrm{MgO}_{4}, \mathrm{MgO}_{5}, \mathrm{MgO}_{6}, \mathrm{MgO}_{7}, \mathrm{MgO}_{8}, \mathrm{MgO}_{9}, \mathrm{MgO}_{10}, \mathrm{MgO}_{11}, \mathrm{MgO}_{12}$ have great change value when $\mathrm{SiO}_{4}, \mathrm{MgO}_{4}$, $\mathrm{MgO}_{3}, \mathrm{MgO}_{5}$ disappear at $\mathrm{P}=20 \mathrm{GPa}, \mathrm{MgO}_{10}, \mathrm{MgO}_{11}, \mathrm{MgO}_{12}$ appear at $\mathrm{P}=20 \mathrm{GPa}$ and angle distribution $\mathrm{SiO}_{5}$ decreases at $\mathrm{P}=20 \mathrm{GPa}$ and angle distribution $\mathrm{MgO}_{8}, \mathrm{MgO}_{9}$ increase at $\mathrm{P}=20 \mathrm{GPa}$ (Table 9a) leads to very big change of the density of structural unit (Table $9 \mathrm{~b}$ ). The results show that the influence of factors on the structure of $\mathrm{MgSiO}_{3}$ bulk is very big.

Table $9 \mathrm{~b}$. The density of angle distribution of the number of structural units $\mathrm{SiO}_{\mathrm{x}}, \mathrm{MgO}_{\mathrm{x}}$ at temperature $2000 \mathrm{~K}$ with different pressures

\begin{tabular}{lllllll}
\hline Pressure $(\mathrm{GPa})$ & 0 & 20 & 40 & 60 & 80 & 100 \\
\hline $\mathrm{SiO}_{4}$ & 271 & 0 & 0 & 0 & 0 & 0 \\
$\mathrm{SiO}_{5}$ & 537 & 69 & 5 & 0 & 0 & 0 \\
$\mathrm{SiO}_{6}$ & 150 & 983 & 429 & 136 & 57 & 22 \\
$\mathrm{MgO}_{3}$ & 25 & 0 & 0 & 0 & 0 & 0 \\
$\mathrm{MgO}_{4}$ & 109 & 0 & 0 & 0 & 0 & 0 \\
$\mathrm{MgO}_{5}$ & 177 & 0 & 0 & 0 & 0 & 0 \\
$\mathrm{MgO}_{6}$ & 172 & 22 & 9 & 7 & 8 & 5 \\
$\mathrm{MgO}_{7}$ & 84 & 179 & 128 & 137 & 154 & 131 \\
$\mathrm{MgO}_{8}$ & 23 & 598 & 617 & 677 & 742 & 759 \\
$\mathrm{MgO}_{9}$ & 4 & 848 & 1011 & 1064 & 1073 & 1161 \\
$\mathrm{MgO}_{10}$ & 0 & 544 & 648 & 622 & 597 & 590 \\
$\mathrm{MgO}_{11}$ & 0 & 173 & 181 & 158 & 123 & 123 \\
$\mathrm{MgO}_{12}$ & 0 & 26 & 27 & 19 & 13 & 8 \\
\hline
\end{tabular}

\section{Conclusion}

The results show that, $\mathrm{MgSiO}_{3}$ bulk has cube-shaped, nano-size and is determined by Molecular Dynamics (MD) method with Born-Mayer (BM) potential and periodic boundary conditions. Successfully determine the influence of atomic number, temperature $(\mathrm{T})$, pressure $(\mathrm{P})$ at $\mathrm{T}=300 \mathrm{~K}, 2000 \mathrm{~K}$ to the structure of $\mathrm{MgSiO}_{3}$ bulk. Especially, at $\mathrm{T}=2000 \mathrm{~K}$, when increasing $\mathrm{P}$, from $\mathrm{P}=0 \mathrm{GPa}$ to $\mathrm{P}=20 \mathrm{GPa}, 40 \mathrm{GPa}, 60 \mathrm{GPa}, 80 \mathrm{GPa}, 100 \mathrm{GPa}$ leading to the first peak position of RDF moving gradually to left and height $\mathrm{g}(\mathrm{r})$ increases with the links $\mathrm{Si}-\mathrm{Si}, \mathrm{O}-\mathrm{O}, \mathrm{Si}-\mathrm{Mg}, \mathrm{O}-\mathrm{Mg}$, $\mathrm{Mg}-\mathrm{Mg}$ and decreases with the link Si-O. The results are consistent with the results (Wilding et al., 2004; Taniguchi et al., 1997; Lee et al., 2005; Matsui \& Kawamura, 1980; Kubicki \& Lasagna, 1991; Shimoda \& Okuno, 2006). The reason is due to the size effect, when atomic number increases (temperature), the size increases, the energy decreases (increases) and when the pressure increases leading to size decreases, energy increases: When increasing $\mathrm{P}$ at $\mathrm{T}=300 \mathrm{~K}$ the number of structural unit $\mathrm{SiO}_{4}, \mathrm{MgO}_{4}$ appears at $\mathrm{P}=20 \mathrm{GPa}$ and $\mathrm{MgO}_{11}, \mathrm{MgO}_{12}$ disappear at $\mathrm{P}=20 \mathrm{GPa} ; \mathrm{MgO}_{5}$ disappears at $\mathrm{P}=40 \mathrm{GPa}, \mathrm{SiO}_{4}$ disappears at $\mathrm{P}=60 \mathrm{GPa}$. When increasing $\mathrm{P}$ at $\mathrm{T}=2000 \mathrm{~K}, \mathrm{MgO}_{10}, \mathrm{MgO}_{11}, \mathrm{MgO}_{12}$ appear at $\mathrm{P}=20 \mathrm{GPa} ; \mathrm{SiO}_{4}, \mathrm{MgO}_{3}, \mathrm{MgO}_{4}, \mathrm{MgO}_{5}$ disappear at $\mathrm{P}=20 \mathrm{GPa} ; \mathrm{SiO}_{4}$ disappears at $\mathrm{P}=60 \mathrm{GPa}$. This shows that, when increasing $\mathrm{P}$, the structure at $\mathrm{T}=300 \mathrm{~K}$ is always more stable at high temperature $\mathrm{T}=2000 \mathrm{~K}$ leading to the number of structural units, the density of structural units at $\mathrm{T}=2000 \mathrm{~K}$ has a very big change.

\section{Conflict of interests}

The authors declare that there is no conflict of interests regarding the publication of this paper.

\section{References}

Al-Hasni, B. M., \& Mountjoy, G. (2014). A molecular dynamics study of the atomic structure of $(\mathrm{MgO}) \mathrm{x}\left(\mathrm{SiO}_{2}\right) 100-\mathrm{x}$. Journal of Non-Crystalline Solids, 389, 33-44.

Benmore et al. (2010). Structural and topological changes in silica glass at pressure. Phys Rev B, 81, 054105.

Benmore et al. (2011). A Review of High-Energy X-Ray Diffraction from Glasses and Liquids. J. Non-Cryst. Solids, 357, 2632.

Brawer, S. (1985). Americain Ceramic Society. Inc., Columbus.

Cormier, L., \& Cuello, G. J. (2011), Mg coordination in a $\mathrm{MgSiO}_{3}$ glass using neutron diffraction coupled with isotopic substitution. Physical Review B, 83, 224-204. 
Dorschner et al. (1995). Steps toward interstellar silicate mineralogy II. Study of Mg-Fe-silicate glasses of variable composition Astron. Astron. Astrophys, 300, 503-20.

Dung, N. T. (2018). The Influence of Temperature, the Pressure at Room, Temperature, the Pressure at High Temperature on Structure and Heterogeneous Dynamics of $\mathrm{CaSio}_{3}$ Bulk. International Journal of Engineering \& Technology, 7(3.19), 140-154.

Fiquet et al. (2010). Melting of peridotite to 140 gigapascals. Science, 329, 1516-1518. Guignard, M., \& Cormier, L. (2008). Environments of $\mathrm{Mg}$ and $\mathrm{Al}$ in $\mathrm{MgO}-\mathrm{Al}_{2} \mathrm{O}_{3}-\mathrm{SiO}_{2}$ glasses: A study coupling neutron and $\mathrm{X}$-ray diffraction and Reverse Monte Carlo modeling. Chem. Geol., 256, 111.

Helfrich, R., \& Wood, B. J. (2001). The Earth's mantle. Nature (London), 412, 501.

Jallot. (2003). Role of magnesium during spontaneous formation of a calcium phosphate layer at the periphery of a bioactive glass coating doped with MgO. Appl. Surf. Sci., 211, 89 .

Kalampounias, A. G., Nasikas, N. K., \& Papatheodorou, G. N. (2009). Glass formation and structure in the $\mathrm{MgSiO}_{3}-\mathrm{Mg}_{2} \mathrm{SiO}_{4} \mathrm{MgSiO}_{3}-\mathrm{Mg}_{2} \mathrm{SiO}_{4}$ pseudobinary system: From degraded networks to ioniclike glasses. J. Phys. Chem., 131, 114513.

Karki, B. B., Bhattarai, D., \& Stixrude, L. (2007). First-principles simulations of liquid silica: Structural and dynamical behavior at high pressure. Phys Rev B, 76, 104205.

Klotz et al. (1995). Neutron powder diffraction at pressures beyond 25GPa. Appl. Phys. Lett., 66(14), 1735-1737.

Kohara et al. (2011). Relationship between topological order and glass forming ability in densely packed enstatite and forsterite composition glasses. Proc. Natl Acad. Sci. USA, 108(36), 14780-14785.

Kohara, S., Suzuya, K., Takeuchi, K., Loog, C. K., Grimsditch, M., Weber, J. K. R., Tangeman, J. A., \& Key, T. S. (2004). Science, 303, 1649.

Kohara, S., Suzuya, K., Takeuchi, K., Loong, C. K., Grimsditch, M., Weber, J. K. R., Tangeman, J. A., \& Key, T. S. (2004). Science, 303, 1649.

Kono et al. (2016). Ultrahigh-pressure polyamorphism in $\mathrm{GeO}_{2}$ glass with coordination number 6. Proc Natl Acad Sci USA, 113, 3436-3441.

Kono, Y., Park, C., Kenney-Benson, C., Shen, G., \& Wang, Y. (2014). Toward comprehensive studies of liquids at high pressures and high temperatures: Combined structure, elastic wave velocity, and viscosity measurements in the Paris-Edinburgh cell. Phys Earth Planet Inter, 228, 269-280.

Kraxner et al. (2008). In M. Liska, D. Galusek, R. Klement, \& V. Petruska (Eds.), Glass - the Challenge for the 21 st Century (Vol. 39-40, p. 81). Trans Tech, Stafa-Zurich.

Kubicki, J. D., \& Lasaga, A. C. (1991). Molecular dynamics simulations of pressure and temperature influences on $\mathrm{MgSiO}_{3}$ and $\mathrm{Mg}_{2} \mathrm{SiO}_{4}$ melts and glasses. Physics and Chemistry of Minerals, 17(8), 661-673.

Kubicki, J. D., \& Lasagna, A. C. (1991). Molecular dynamics simulations of pressure and temperature effects on $\mathrm{MgSiO}_{3}$ and $\mathrm{Mg}_{2} \mathrm{SiO}_{4}$ melts and glasses. Phys. Chem. Minerals, 17, 661.

Labrosse, S., Hernlund, J. W., \& Coltice, N. (2007). A crystallizing dense magma ocean at the base of the Earth's mantle. Nature, 450, 866-869.

Lay, T., Williams, Q., \& Garnero E. J. (1998). The core-mantle boundary layer and deep Earth dynamics. Nature, $392,461-468$.

Lee et al. (2005). X-ray Raman scattering study of $\mathrm{MgSiO}_{3}$ glass at high pressure: Implication for trio clustered $\mathrm{MgSiO}_{3}$ melt in Earth's mantle. Nature Mater.

Liebau, F. (1984). Pentacoordinate silicon intermediate states during silicate condensation and decondensation. Crystallographic support. Inorg. Chim. Acta, 89, 1.

Lin, C., Chen, S. F., Liu, L. G., \& Li, C. C. (2007). Anionic structure and elasticity of $\mathrm{Na}_{2} \mathrm{O}-\mathrm{MgO}-\mathrm{SiO}_{2}$ glasses. $J$. Non-Cryst. Solids, 353, 413.

Matsui, Y., \& Kawamura, K. (1980). Instantaneous structure of an $\mathrm{MgSiO}_{3}$ melt simulated by molecular dynamics. Nature (London), 285, 648.

Meade, C., Hemley, R. J., \& Mao, H. K. (1992). High-pressure X-ray diffraction of $\mathrm{SiO}_{2}$ glass. Phys Rev Lett, 69 , 1387-1390. 
Molster et al. (1999). Low-temperature crystallization of silicate dust in circumstellar disks. Nature (London), 401, 563.

Murakami, M., \& Bass, J. D. (2010). Spectroscopic evidence for ultrahigh-pressure polymorphism in $\mathrm{SiO}_{2}$ glass. Phys Rev Lett, 104, 025504.

Murakami, M., \& Bass, J. D. (2011). Evidence of denser $\mathrm{MgSiO}_{3}$ glass above 133 gigapascal (GPa) and implications for remnants of ultradense silicate melt from a deep magma ocean. Proc Natl Acad Sci USA, 108, 17286-17289.

Nguyen, T. D. (2017). Some Factors Affecting Structure, Transition Phase and Crystallized of CuNi Nanoparticles. American Journal of Modern Physics, 6(4), 66-75.

Nguyen, T. D., Nguyen, C. C., \& Tran, V. H. (2017). Molecular dynamics study of microscopic structures, phase transitions and dynamic crystallization in Ni nanoparticles. RSC Adv., 7, 25406-25413.

Nomura et al. (2011). Spin crossover and iron-rich silicate melt in the Earth's deep mantle. Nature, 473, $199-202$.

Nomura et al. (2014). Low core-mantle boundary temperature inferred from the solidus of pyrolite. Science, 343, $522-525$.

Nos'e, S. (1984). A unified formulation of the constant temperature molecular dynamics methods. J. Chem. Phys., 81, 511-519.

Pedone, M. M., \& Menziani, C. (2009). Computational Insight into the Effect of CaO/MgO Substitution on the Structural Properties of Phospho-Silicate Bioactive Glasses. J. Phys. Chem. C, 113, 15723.

Pedone, M. M., Menziani, C., Segre, U., \& Cormack, A. N. (2008). Add paper title here. J. Phys. Chem. C, 112, 11034.

Petitgirard et al. (2015). Fate of $\mathrm{MgSiO}_{3}$ melts at core-mantle boundary conditions. Proc Natl Acad Sci USA, 112, 14186-14190.

Prescher et al. (2017). Beyond sixfold coordinated $\mathrm{Si}$ in $\mathrm{SiO}_{2}$ glass at ultrahigh pressures. Proc Natl Acad Sci USA, 114, 10041-10046.

Qi, Y., Ça gin, T., Johnson, W. L., \& Goddard III, W. A. (2001). Melting and crystallization in Ni nanoclusters: The mesoscale regime. J. Chem. Phys., 115, 385-394.

Sanloup et al. (2013). Structural change in molten basalt at deep mantle conditions. Nature, 503, 104-107.

Sanloup, C. (2016). Density of magmas at depth. Chem Geol, 429, 51-59.

Sato, T., \& Funamori, N. (2008). Sixfold-coordinated amorphous polymorph of $\mathrm{SiO}_{2}$ under high pressure. Phys Rev Lett, 101, 255502.

Sato, T., \& Funamori, N. (2010). High-pressure structural transformation of $\mathrm{SiO}_{2}$ glass up to 100GPa. Phys Rev B, $82,184102$.

Sato, T., \& Funamori, N. (2010). High-pressure structural transformation of $\mathrm{SiO}_{2}$ glass up to $100 \mathrm{GPa}$. Phys. Rev. $B, 82,184102$.

Schilling et al. (2001). Compositional dependence of elastic properties and density of glasses in the system anorthite-diopside-forsterite. Contr. Miner. Petrol., 141, 297.

Sen, S., Maekawa, H., \& Papatheodorou, G. N. (2009). J. Phys. Chem. B, 113, 15243.

Shimoda, K., \& Okuno, M. (2006). Molecular dynamics study of $\mathrm{CaSiO}_{3}-\mathrm{MgSiO}_{3}$ glasses under high pressure. $J$. Phys. Condens. Matter, 18, 6531.

Shimoda, K., \& Okuno, M. (2006). Molecular dynamics study of $\mathrm{CaSiO}_{3}-\mathrm{MgSiO}_{3}$ glasses under high pressure. $J$. Phys. Condens. Matter, 18, 6531.

Spera et al. (2011). Structure, thermodynamic and transport properties of liquid $\mathrm{MgSiO}_{3}$ : $\mathrm{Comparison}_{\text {of }}$ molecular models and laboratory results. Geochimica et Cosmochimica Acta, 75, 1272-1296.

Stixrude, L., \& Karki, B. (2005). Structure and freezing of $\mathrm{MgSiO}_{3}$ liquid in Earth's lower mantle. Science, 310 , 297-299.

Taniguchi et al. (1997). X-ray diffraction and EXAFS studies of silicate glasses containing Mg, Ca and Ba atoms. Journal of Non-Crystalline Solids, 211(1-2), 56-63. 
Taniguchi, T., Okuno, M., \& Matsumoto, T. (1997). X-ray diffraction and EXAFS studies of silicate glasses containing $\mathrm{Mg}$, Ca and Ba atoms. J. Non-Cryst. Solids, 56, 211.

W. G. Hoover, W. G. (1985). Canonical dynamics: Equilibrium phase-space distributions. Phys. Rev. A, 31, 1695-1697.

Wang et al. (2014). Atomistic insight into viscosity and density of silicate melts under pressure. Nat Commun, 5, 3241.

Wilding et al. (2004). Coordination changes in magnesium silicate glasses. Europhys. Lett., 67(2), 212-218.

Wilding, M. C., Benmore, C. J., Tangeman, J. A., \& Sampath, S. (2004). Europhys. Lett., 67, 212.

Williams, Q., \& Garnero, E. J. (1996). Seismic evidence for partial melt at the base of Earth's mantle. Science, 273, $1528-1530$.

\section{Copyrights}

Copyright for this article is retained by the author(s), with first publication rights granted to the journal.

This is an open-access article distributed under the terms and conditions of the Creative Commons Attribution license (http://creativecommons.org/licenses/by/4.0/). 